Pamiętnik Literacki 2014, 1, s. 45-83
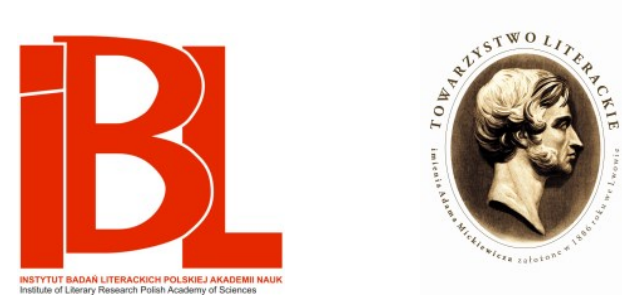

\title{
Miłosz, Mickiewicz, Rosja
}

Małgorzata Zemła 
Pamiętnik Literacki CV, 2014, z. 1, PL ISSN 0031-0514

MAŁGORZATA ZEMŁA Ludwig-Maximilians-Universität, München

MIŁOSZ, MICKIEWICZ, ROSJA

\section{Literacka psychoanaliza według Miłosza}

Zadanie, które Czesław Miłosz postawił sobie w Rosji, mianowicie prześwietlenie wzajemnych stosunków Polaków i Rosjan, było w czasie pisania tego eseju trudne, jeżeli nie karkołomne. Powody, dla których podjął się takiego tematu, poeta wyjaśnia dopiero pod koniec utworu. Wskazuje tu przede wszystkim na deficyt naukowych dyskursów epoki, który jego esej mógłby skompensować:

Wiek XX, w panicznym strachu przed bredniami nacjonalistów i rasistów, usiłuje zasypać przepaść czasu cyframi produkcji czy nazwami kilku polityczno-gospodarczych systemów, wyrzekając się badań nad misterną tkaniną stawania się, gdzie żadna nitka nie powinna być pominięta [...]. Co było, znika na zawsze tylko pozornie, w istocie transformuje się niepostrzeżenie [...]. Kiedy jeszcze opis krajów i cywilizacji nie był obwarowany mnóstwem zakazów wynikających z podziału wiedzy na szufladki, autorzy, najczęściej podróżnicy, nie lekceważyli czasu, jaki zastyga w spadziźnie dachu, w wygięciu rękojeści pługa, w geście i przysłowiu. Reportażysta, socjolog i historyk mogli wtedy współżyć w jednym człowieku, zanim nie rozłączyli się, ze wzajemną dla siebie szkodą. [...]

Wiedza nasza nie rozwija się równomiernie, postępując w jednych dziedzinach, drepcząc na miejscu albo nawet cofając się w innych. Jej dzisiejszy lęk przed uogólnieniami dotyczącymi ludnościowych i terytorialnych zespołów jest szacowną pobudką, bo chroni od popadnięcia w służbę ludzi zainteresowanych nie tyle prawdą, ile doraźnym argumentem w politycznej walce. Dopiero kiedy znikną powody do takiego lęku, umysł wyćwiczony w tropieniu współzależności przeniknie w to, co teraz jest dla mądrych tylko wstydliwe, odsunięte jako przedmiot rozmów przy stole w parafialnej oberży. [M 165-166] ${ }^{1}$

Wyliczone tu braki i dezyderaty przypominają programowe artykuły francuskiej nouvelle histoire, której założyciel, Fernand Braudel, postulował ścisłą współpracę badań długiego trwania (longue durée) z socjologia i geografią, czy późniejszej historii mentalności oraz imagérie culturelle. Jest jednak mało prawdopodobne, aby Miłosz studiował dzieła Braudela; w cytowanym fragmencie poeta powołuje się przecież nie na dzieła historyków, lecz na przednaukowe osiagnnięcia podróżników. W swoim eseju na ogół nie podąża zresztą śladami ani zawodowych historyków, ani podróżników amatorów. Zamiast tego bez parady obnaża właściwy Polakom stereotyp (by nie powiedzieć od razu: przesąd) na temat Rosji i poddaje osobiście siebie oraz cała polską zbiorowość literackiej psychoanalizie ${ }^{2}$. Rosja to zresztą

1 Skrótem M odsyłam do: Cz. Mił o s z, Rosja. W: Rodzinna Europa. Kraków 2001. Dzieła zebrane.

2 Miłosz wielokrotnie odnosił się niechętnie zarówno do psychoanalizy freudowskiej, jak i do J.-P. Sartre'a. Jednak Sartre'owska analiza egzystencjalna bardzo go pociagała. Zob. następująca wypowiedź poety: „Bardzo nie lubię Sartre’a. Chociaż wykładając Dostojewskiego używałem ana- 
chyba jedyny przypadek, kiedy poeta tak otwarcie przyznaje się do przynależności do tej wspólnoty i rezygnuje ze zwykle narzucanego sobie dystansu, gdzie troska skrywana jest zwykle pod maską sarkazmu, ćwiczonego na Stanisławie Brzozowskim. Sposób postępowania Miłosza w eseju Rosja ma zresztą nie tylko polskie, lecz również ogólnoeuropejskie tło, i związany jest ze specyfiką dyskursu na temat tego kraju. Szczególna rola, która odgrywała Rosja w ciagu wieków w kulturze europejskiej, spowodowała, że dyskurs o tym kraju i jego kulturze był na ogół uzależniony od ideologii danego obozu politycznego. Pozycja Polski jako kraju podbitego przez Rosję od roku 1772 do końca lat osiemdziesiątych wieku XX (wyłączając intermezzo między dwiema wojnami światowymi) w tym dyskursie przedstawiała się jako wyjątkowo drażliwa. Model komunikacji, który wykształcił się między Polakami a Rosjanami już w wieku XIX, odzwierciedlał socjopatyczny stosunek podwójnego wiązania (ang. „double bind”) ${ }^{3}$. We wzajemnych relacjach rosyjsko-polskich wiele było zwrotów i pojednań, lecz pewien sposób postępowania rosyjskich i radzieckich władz politycznych wobec Polski ustalił się w pamięci zbiorowej Polaków jako powtarzający się od czasów Katarzyny Wielkiej aż po kres PRL-u. Przemoc wywieraną na Polskę decydenci polityczni obcego mocarstwa często prezento-

lizy, takiej niby tzw. egzystencjalnej psychoanalizy, czy też jak inaczej można te głupstwa nazwać. Ale tak nazywaja jedna z części L'Être et le Néant Sartre’a. Analiza miłości, analiza stosunków, powiedzmy, ról kelnera itd." (Czesława Miłosza autoportret przekorny. Rozmowy przeprowadził A. Fiut. Kraków 1994, s. 94). Atrakcyjne dla Miłosza było przeformułowanie przez J.-P. S a rtr e’a (Byt i nicość. Zarys ontologii fenomenologicznej. Przeł. J. Ki ełb a s a [i in.]. Kraków 2007, s. 691) pojęcia pożądania. U Freuda oznacza ono impuls libidalny pochodzący z podświadomości, Sartre natomiast umieszcza je w świadomości i przenosi jego działanie na ogół aktywności człowieka w świecie: „Podobnie Stendhal [...] oraz Proust [...] - czyż obaj nie wykazywali, że miłość i zazdrość nie dają się sprowadzić do samego pragnienia posiadania d a n ej kobiety, lecz że zmierzają one do przeniknięcia p o p r z e z kobietę do świata jako całości? Taki jest sens Stendhalowskiej krystalizacji [...]". Po Sartrze wszystkie elementy naszego istnienia w świecie mogą stać się przedmiotem psychoanalizy, dopuszczalne jest również połączenie psychoanalizy $\mathrm{z}$ historią. $\mathrm{W}$ dziele o G. Flaubercie zajmuje się J.-P. Sartre (Idiota $w$ rodzinie. Wybór tekstów z niedokończonej monografii. Wybór W. Sa dk ow ski. Przeł. J. W a c zków. Gdańsk 2000) właśnie „powszechną, historyczną neurozą", którą łączy z „subiektywnym Flaubertem”. Zmiany dokonane przez Sartre'a w rozumieniu pojęcia pożądania sprawiły, że psychoanaliza stała się dla Miłosza atrakcyjna. $Z$ drugiej strony jednak Miłosz w całej swojej twórczości wykazuje skłonność do literackich procedur, których wspólną cechą jest sięganie do głębi, pod powierzchnię zdarzeń, również sięganie do podświadomości. Tymczasem Sartre negował istnienie tej ostatniej. Dlatego literacką psychoanalizę, którą Miłosz przeprowadza w Rosji, należy uznać za połączenie koncepcji Sartre’a i Freuda.

Teoria podwójnego wiązania pierwotnie miała wyjaśniać powstawanie schizofrenii poprzez panujące w rodzinie chorego wzory komunikacyjne. Jej zastosowanie w psychiatrii jest kontrowersyjne, uznaniem cieszy się natomiast w teoriach komunikacji. Koniecznymi składnikami układu podwójnego wiązania sa przynajmniej dwie osoby lub strony, które komunikują się ze sobą przez dłuższy czas, przy czym jedna strona układu ma daleko idącą władzę nad drugą. Powtarzanie się pewnego schematu komunikowania prowadzi do ustalenia określonego wzoru bodźca i reakcji. Podwójne komunikaty wysyłane przez opresora charakteryzują się paradoksalnością: strona posiadająca władze zapowiada np. stosowanie bolesnych środków nacisku wobec strony zależnej, jako dla tej ostatniej szczególnie dobroczynne. Wszystkie próby ofiary - mające na celu stworzenie metadyskursu na temat podwójnego komunikatu - sa jednocześnie uniemożliwiane przez opresora. Zob. G. Bates on, D. D. J a cks on, J. Haley, J. H. We akland, Auf dem Weg zu einer Schizophrenie-Theorie. W zb.: Schizophrenie in der Familie. Beiträge zu einer neuen Theorie. Frankfurt am Main 1984 (wyd. 1, amerykańskie: 1962). 
wali przy tym jako pomoc „braterska”, w sensie: duży i silny brat Słowianin próbuje pomóc słabowitemu bratu słowiańskiemu, gdyż ten ostatni, pozostawiony samemu sobie, nie byłby zdolny do życia i nie wiedziałby, co dla niego dobre. Gdy ta polityczna, administracyjna i w końcu również militarna aktywność opresora napotykała na opór ze strony polskiej (co stanowiło regułę), interpretowano bunt jako niewdzięczność i zuchwalstwo wynikające z niedojrzałości „krewnego” i usprawiedliwiano w ten sposób późniejsze represje.

W przeciwieństwie do opisywanych - przez zespół Gregory’ego Batesona - rodzin, gdzie dzieci były całkowicie bezbronne wobec podwójnych komunikatów wysyłanych przez dorosłych członków rodziny, elity, a często także szerokie rzesze polskiego społeczeństwa, doskonale zdawały sobie sprawę z manipulacji, której część stanowiły owe komunikaty. Równie dobrze uświadamiano sobie fakt, że ta propagowana przez opresora „rodzina słowiańska” jest tylko pseudowspólnotą ${ }^{4}$. W warunkach politycznego przymusu powstanie metadyskursu, który zdołałby wyjaśnić wzajemne skomplikowane powiązania, nie było możliwe. Również Miłosz uważa za nierealne ukształtowanie podmiotu swojego eseju jako niezaangażowanego obserwatora - przeciwnie, musi on najpierw sprostać własnej roli ofiary. W opisach psychiatrycznych układu podwójnego wiązania podtrzymywanie negatywnego obrazu opresora jest wręcz konieczne dla zachowania własnej integralności. W Rosji zostaje wprawdzie zainicjowany proces psychoanalityczny, w którego efekcie nieprzejednana polaryzacja stanowisk mogłaby być uchylona; w eseju pojawia się też propozycja potraktowania tematu, zdolna działać inspirująco na metodologię studiów kulturowych - podobne idee były przecież natchnieniem badaczy z tartusko-moskiewskiej szkoły semiotyki, przede wszystkim zaś Jurija Łotmana. Ostatecznie jednak polskiemu poecie nie udaje się uwolnić od uwikłań wynikających z podwójnego wiązania. Najważniejsze dla Miłosza jest obnażenie kompleksu, który podmiot eseju dzieli ze swoją wspólnotą narodową. Już na początku Rosji podmiot ten deklaruje, że jego nastawienie do tematu cechuje się obsesyjnością:

Nie ma sensu udawać, że jest się wyjątkiem, i ukrywać obsesję, właściwą wszystkim Polakom. Przeciwnie, trzeba się do niej przyznać i starać się ją badać w sobie samym możliwie beznamiętnie. [M 146]

„Obsesja” to według Słownika języka polskiego "objaw nerwic i psychonerwic, polegający na myślach i czynnościach natrętnych, od których chory nie może się uwolnić; natręctwo; potocznie także: myśl prześladująca kogoś uporczywie, uraz na jakimś tle'5 . Przyczyną obsesji są często przeżycia traumatyczne, uzewnętrzniające się np. dzięki psychoanalizie. Cytowany fragment stanowi zapowiedź właśnie procesu psychoanalitycznego, w którym podmiot eseju odgrywa na zmianę rolę analityka i pacjenta ${ }^{6}$. Procesualność myślenia, tak charakterystyczna dla poetyki

4 Zob. L. C. Wy nne, I. M. Ry ck off, J. D ay, S. J. Hir s c h, Pseudogemeinschaft in den Familienbeziehungen der Schizophrenen. W zb.: jw.

5 Słownik języka polskiego. Red. nauk. M. Szy mczak. Oprac. haseł A. Bańkowska [i in.]. T. 2. Warszawa 1979.

$6 \quad$ W tym miejscu trzeba również przypomnieć, że pojęcie obsesji w ogóle odgrywa w poetyce Miłosza dużą rolę. Termin „obsesja” bywa u niego używany wymiennie z takimi jak „osłupienie”, „olśnienie”, 
eseju, realizowana jest w Rosji właśnie w postaci literackiego procesu psychoanalitycznego.

W procesie tym da się wyróżnić trzy etapy i postaram się je tu przeanalizować. Najpierw Miłosz rozpatruje historyczne i socjologiczne tło polsko-rosyjskiego kompleksu. Jednocześnie odsłania stereotypy i przesądy, które we wzajemnych stosunkach Polaków i Rosjan zdają się odgrywać znaczącą rolę. Miejsce centralne zajmuje tutaj - jakże mogłoby być inaczej - Ustęp części trzeciej Dziadów Adama Mickiewicza, utwór, który Miłosz nazywa „s u m m ą polskiego stosunku do Rosji” (M 150). Poeta nie analizuje stereotypu, nie stawia go pod znakiem zapytania, lecz przede wszystkim - podobnie jak to się dzieje w realnym procesie psychoanalitycznym - obnaża ukryte, wstydliwe treści kolektywnej psyche i jej obsesje. Negatywne emocje podmiotu eseju (a pewnie także i czytelnika, który, zależnie od przyjętej przez niego perspektywy, równie emocjonalnie tę część Rosji zaakceptuje lub odrzuci) potęgowane są aż do pewnego rodzaju ekstazy. Rosja staje się przy tym ucieleśnieniem tego, co Sigmund Freud nazywał „unheimlich” (niesamowite) ${ }^{7}$.

W drugiej części literackiej psychoanalizy Miłosza dochodzi do ujawnienia przez podmiot eseju ukrytych treści własnej psyche, pewnego rodzaju tabu. Zaraz potem następuje nagłe i nieoczekiwane uświadomienie sobie przez ten podmiot traumatycznego przeżycia wojennego.

Ostatnią część uznać należy za właściwą analizę: „das Unheimliche” (niesamowitość) okazuje się, podobnie jak u Freuda, wypartą częścią siebie. Bezpośrednio po tej rewelacji Miłosz przedstawia projekt dyskursu o Rosji, który może zastąpić przesą na jej temat. Propozycje Miłosza będą tutaj porównane $z$ pracami semiotyków szkoły tartusko-moskiewskiej, przede wszystkim Łotmana.

„ekstaza" i inne, symbolizuje "wywołany świadomie lub występujący bez udziału woli stan, w którym podmiot doznaje objawienia bytu lub sensu'. Do tej pory badacze zajmowali się przede wszystkim znaczeniem tego terminu dla sakralnych treści utworów Miłosza (zob. szczególnie artykuł J. Błoń s ki e go Epifanie Miłosza 〈w: Miłosz jak świat. Kraków 1984〉 oraz Sylwy wspótczesne R. Ny c za (Wrocław 1984, s. 46〉). Warto przywołać następujące ustalenia Ny c za (op. cit., s. 46): „Podstawą zarówno egzystencjalnego, jak poetyckiego doświadczenia Miłosza jest, jak wiadomo, odczucie konkretu, tego, co realnie istnieje. Wnikliwe studia Jana Błońskiego dowiodły, że formą tego odczucia jest epifania, owa "nagła manifestacja duchowości» (określenie Joyce’a), przydarzająca się podmiotowi w świecie codziennego życia. Jednak niełatwo jest zrozumieć, na czym to doświadczenie polega, czego dotyczy, co w nim wychodzi na jaw. Najogólniej można przecież powiedzieć, że, wprawiając w stan podobny "obsesji" czy "osłupieniu" [...], daje ono poczucie radykalnej bliskości Innego, istotnego kontaktu z tym, co "niedosiężne", obecności sacrum czy źródłowego sensu". Jednak obsesja i olśnienie mają u Miłosza bardziej uniwersalne znaczenie i odnoszą się również do treści świeckich. Pojęcie obsesji i następującego po niej olśnienia lub objawienia związane jest także $z$ gnozą.

7 S. Fre ud, Niesamowite. W: Pisma psychologiczne. Przeł. R. Res z ke. Warszawa 1997. Dzieła. T. 3. Niemiecki termin tłumaczy się na język polski jako „niesamowite”, choć nie jest to tłumaczenie do końca zadowalające. Pośród objawów zewnętrznych wywołujących odczucie niesamowitości Freud wylicza „wątpliwości w uduchowienie istoty pozornie żywej i - odwrotnie - wątpliwości, czy jakiś przedmiot nieożywiony jest [...] obdarzony duszą [...]" (ibidem, s. 241) i przytacza przykłady z dzieł niemieckich romantyków, w których wahanie to dotyczy pozornie żywych lalek i automatów. 


\section{Realizm i przesąd: Polacy i Rosjanie w pierwszej części ${ }^{8}$ Rosji}

1. Na początku eseju Miłosz próbuje znaleźć ogólną formułę dla wzajemnych wyobrażeń Polaków i Rosjan, którą dałoby się odnieść również do innych narodów:

Być może, wszystkie narody, zobaczone jako całość, a nie jako zespół jednostek, są odrażające i sąsiedzi odkrywają na ich przykładzie tylko niemiłą prawdę o społeczeństwach ludzkich w ogóle. Nie jest wykluczone, że Polacy wiedzą o Rosjanach to, co Rosjanie wiedzą o sobie samych, nie chcąc się do tego przyznać, i odwrotnie. [...] Prawdopodobnie też każde zetknięcie z Rosjanami jest dla Polaków przykre i nastraja ich obronnie, bo demaskuje ich wobec [...] [nich] samych. [M 146]

Mimo zadeklarowanej na początku obsesji na temat Rosji podmiot eseju stara się tu przyjąć pozycję neutralną. Poglądy swoje wypowiada ostrożnie - każde zdanie rozpoczyna się cenionymi już przez Michela de Montaigne’a „miarkującymi” wyrażeniami: „być może”, „nie jest wykluczone”, lub przymiotnikiem „prawdopodobne”. Opinia zyskuje dzięki temu pewną przelotność, zachęca do współmyślenia, czyli ma wszystkie cechy eseistycznego „myślenia w ruchu”, jak to nazwał Jean Starobinski ${ }^{10}$. A myślenie wydaje się tu niezbędne, ponieważ kolektywna wiedza narodów o sąsiadach jest $z$ konieczności stereotypowa i niewolna od przesądów. Owa kolektywna, przekazywana z pokolenia na pokolenie „wiedza” stanowi przedmiot rozważań Miłosza w pierwszej części Rosji. Zanim jednak będzie można przyjrzeć się bliżej obchodzeniu się poety $\mathrm{z}$ ta wiedzą, trzeba nam przedstawić sposoby definiowania pojęć stereotypu, przesądu i im pokrewnych w naukach humanistycznych.

2. Terminy „stereotyp”, „przesad”, ,image” i inne nie sa w nauce jasno rozgraniczone. Pojęcie stereotypu przeszło w ciagu ostatnich kilku dekad liczne przemiany. Wywodzi się ono z nauk o mediach, a wprowadził je do nich w latach dwudziestych ubiegłego wieku Walter Lippmann ${ }^{11}$. Stereotypią nazywa się technikę druku stosowana przed wprowadzeniem składu komputerowego. Technika ta umożliwia masowe powielanie tekstów dzięki matrycom, zestawionym z poszczególnych liter. „Stereotypia przekształca więc pewną zmienną strukturę $\mathrm{w}$ trwała i niezmienna formę" ${ }^{2}$. Lippmann podkreśla różnicę, jaka istnieje między „world outside” a „pictures in our heads”: w „naszych głowach” rzeczywistość przemieniona zostaje przez intelekt w uproszczone konstrukcje, jakimi na co dzień się posługujemy. Stereotypizacja jest według Lippmanna uniwersalnym sposobem, który pozwala nam radzić sobie $\mathrm{z}$ nadmiarem informacji. Stereotypy charakteryzowane sa przy tym przez stałość i uniwersalność. Trudno na nie wpływać, a jeszcze trudniej je zmienić. Stereotyp Lippmanna nie traci jednak kontaktu z rzeczywistością i cechuje go pewna ambiwalencja.

8 Wyodrębnienie części eseju jest umowne, Miłosz nie dokonuje takiego podziału.

9 Zob. M. de Montaigne, Próby. Przeł. T. B oy-Żeleński. Oprac., wstęp, komentarz Z. Gi er c zyń s ki. T. 3. Warszawa 1985, s. 251: „Lubię te słowa, które łagodzą i miarkują śmiałość naszych twierdzeń: "być może", "poniekąd", "po części", "powiadają", "mniemam", i tym podobne".

10 J. Starobins ki, Montaigne en mouvement. Paris 1982.

11 W. Li p pma n n, Public Opinion. New York 1922.

12 H. J. Kl e in s t e u b e r, Stereotype, Images und Vorurteile-die Bilder in den Köpfen der Menschen. W zb.: Die hässlichen Deutschen? Deutschland im Spiegel der westlichen und östlichen Nachbarn. Red. G. Trautmann. Darmstadt 1991, s. 61 n. 
To bardzo ogólne pojęcie stereotypu zostało przyswojone i przekształcone przez socjologów. Za reprezentatywne zwłaszcza dla lat sześćdziesiątych i siedemdziesiątych XX wieku można w tym wypadku uznać definicje Adama Schaffa' ${ }^{13}$. Schaff używa terminu „stereotyp” szczególnie w odniesieniu do określonych grup społecznych (ras, narodowości, klas, grup politycznych, zawodów, płci). Tak rozumiany stereotyp jest wpajany jednostce przez zbiorowość - przez rodziców i otoczenie, wykazując przy tym odporność nawet na przeczace mu doświadczenie. Naturalnie to silne nasycenie emocjami decyduje o długowieczności stereotypu.

Związek stereotypu z rzeczywistością definiuje Schaff inaczej niż Lippmann. Dla tego ostatniego stereotyp to produkt spontanicznej próby opanowania rzeczywistości, próby, która w sposób nieunikniony prowadzi do jej uproszczenia i unieruchomienia. Podstawowy związek stereotypu z rzeczywistością nie zostaje jednak przez Lippmanna podważony. Jeśli chodzi natomiast o przekazywane z pokolenia na pokolenie mądrości ludowe, służące głównie oddzieleniu własnej wspólnoty od innych, to - według wielu uczonych opisywanego okresu - wiedza przekazywana w stereotypach może odnosić się tylko do wspólnoty, która ten stereotyp wytworzyła. Tego zdania był pod koniec lat siedemdziesiątych XX wieku np. historyk Andrzej Garlicki:

Stereotypy mówią nam niewiele o tych, których dotyczą. Bardzo wiele natomiast o tych, którzy je wytworzyli. O ich mentalności, wiedzy, horyzoncie geograficznym. Analiza cech ocenianych u cudzoziemców pozwala w jakiejś mierze odtworzyć światopogląd oceniającego ${ }^{14}$.

Taka definicja stereotypu zbliża go do przesądu w sensie, jaki nadała mu psychologia społeczna. Pojęcie to stosowane było głównie w badaniach antysemityzmu i rasizmu (skierowanego przeciwko Afroamerykanom w USA). Przesąd różni się jednak od stereotypu, gdyż, zdaniem Anitry Karsten, brak mu tak charakterystycznej dla tego pierwszego ambiwalencji:

Przez przesąd rozumiem [...] uprzedzony i negatywny pogląd o grupie ludzi [...], pogląd emocjonalnie nacechowany i nie zgadzający się z rzeczywistością. [...] Pogląd pozytywny mogę nazwać przesądem tylko wtedy, gdy służy odrzuceniu tych ludzi, którzy do mojej grupy nie należą ${ }^{15}$.

Stereotyp (np. w definicji Schaffa) wydaje się dzieckiem bezimiennej tradycji, przesąd natomiast jest zawsze produktem manipulacji:

Dopiero kiedy fałszywy pogląd i uprzedzone zdanie utrzymane zostają mimo wiedzy, że jest inaczej, lub/i nie rezygnuje się $z$ nich $z$ powodów emocjonalnych, lenistwa myślowego i bierności czy innych nierzeczowych powodów, dopiero wtedy mówimy o przesądach ${ }^{16}$.

W przypadku przesądów mamy do czynienia zawsze $z$ tymi, którzy manipulują, i tymi, którzy są manipulowani (albo z takimi, którzy autorytarnych słów manipu-

13 A. Schaff, Stereotyp: definicja i teoria. „Kultura i Społeczeństwo” 1978, nr 3.

14 A. Garlicki, przedmowa w zb.: Sasiedzi $i$ inni. Red. nauk. ... Warszawa 1978, s. 5.

15 A. Karsten, Das Vorurteil. (Sammelreferat). W zb.: Vorurteil. Ergebnisse psychologischer und sozialpsychologischer Forschung. Hrsg. ... Darmstadt 1978, s. 122 n.

16 Ibidem, s. 123. 
latorów używają dla własnej wygody, zwalniając się w ten sposób z wszelkiej odpowiedzialności).

Następna różnica między stereotypem a przesądem polega na tym, że pierwszy służy głównie oddzieleniu czy wyodrębnieniu własnego kolektywu z pozostałych ( w tym sensie spełnia on raczej d e f e n s y w n e zadania - Lippmann mówi dosłownie o „stereotypach jako obronie”), drugi natomiast mniej czy bardziej a k ty w ni e zwalcza inne zbiorowości (przede wszystkim narodowości i rasy) i używany jest często do usprawiedliwienia czynów nawet haniebnych. Przeciwko tak zdefiniowanym przesądom należy stosować działania prewencyjne, szczególnie w dziedzinie nauki i kultury. Wyobrażenie natomiast, że można całkowicie pozbyć się stereotypów, jest iluzoryczne. Lippmann nawoływał dziennikarzy do ostrożnego i odpowiedzialnego obchodzenia się ze stereotypami, aby nie dopuścić do przekształcania się ich w przesądy.

Posługiwanie się tak zdefiniowanymi pojęciami stereotypu i przesądu jest często problematyczne choćby $\mathrm{z}$ tego powodu, że istnieje między nimi wiele form pośrednich. Występują one nierzadko w literaturze pięknej (nie mam tu na myśli literatury użytkowej). Obraz Polaków w powieściach Fiodora Dostojewskiego okazuje się tak uproszczony i jednoznacznie negatywny ${ }^{17}$, iż nie można go traktować inaczej niż jako przesąd. Jednak przesąd ów ma, jak się wydaje, raczej defensywny charakter. Jeszcze bardziej skomplikowane jest to w wypadku portretów, które ofiary - także całe narody - tworzą swoim okupantom czy nawet katom. Autorzy redukuja te wizerunki często do treści negatywnych. Mickiewicz w swoim oszałamiającym wybuchu nienawiści do Rosji, jaki stanowi Ustęp do części trzeciej Dziadów, niewątpliwie nie jest ani wyważony, ani sprawiedliwy. Czy jednak tego rodzaju emocje mogą dziwić wobec faktu zdławienia przez Rosję powstania listopadowego? Mickiewicz chciał zaszkodzić wizerunkowi Rosji na Zachodzie, lecz cel ów został chybiony, ponieważ dzieło zostało umieszczone przez Święte Przymierze na indeksie i nie poświęcono mu w Europie wiele uwagi. Natomiast samym Polakom towarzyszyło wiernie przez długie dziesięciolecia zaborów. Przypadek Mickiewicza pozwala nam dostrzec temat raczej omijany przez badaczy literatury, mianowicie przesądy ofiar. Wydaje się, że zredukowane do samych negatywów poglądy na temat wrogów, poglądy, których nie sposób nazwać inaczej niż przesądami, często pomagają ofiarom przetrwać. Nie należy jednak jeszcze tracić z oczu pytania: kiedy wolno od ofiar wymagać, by pożegnały się ze swymi przesądami? Czyż pielęgnowanie obrazu samego siebie jako ofiary nie obraca się kiedyś przeciwko samej ofierze?

Nowsze badania przeczą historycznej niezmienności stereotypów i przesądów. Wyobrażenia o innych narodach mają bez wątpienia swoje dzieje, niektóre z nich daja się prześledzić aż do wypraw krzyżowych. Cechą stereotypów jest też ich ambiwalencja. Np. obraz Polaków w Niemczech już w bardzo pobieżnym oglądzie ukazuje janusowe oblicze: imago szlachetnego Polaka walczącego o wolność konkuruje w nim $\mathrm{z}$ „polnische Wirtschaft” (polska gospodarka), a oba wiążą się z konkretnym podłożem historycznym. Przy tym tylko druga część stereotypu ma

$17 \quad Z$ wyjątkiem wczesnej powieści Zapiski $z$ domu umarłych, w której obraz polskich zesłańców jest wyjątkowo pozytywny. 
funkcje odgraniczające; pierwsza - wręcz przeciwnie, jest dla Polaków przepustką do wspólnoty narodów ceniących wolność. Na początku lat dziewięćdziesiątych $\mathrm{XX}$ wieku widziało się np. w Niemczech, jak szybko i gładko imago szlachetnego Polaka, mogącego służyć za wzór bojownika o wolność w Europie Środkowo-Wschodniej, daje się wymienić na stereotyp spryciarza i złodzieja samochodów. Obie części stereotypu nie występują zwykle razem, ale jego uśpiona część pozostaje tuż pod progiem świadomości i zachowuje funkcję łagodzącą lub korygującą część drugą. Nie do utrzymania dzisiaj jest również rozpowszechniony w latach siedemdziesiątych XX wieku pogląd, wedle którego stereotypy i przesądy tworzą się i funkcjonują w oderwaniu od sąsiadów. Wolno odnieść wrażenie, iż badacze przesądów w tej dekadzie - i w Stanach Zjednoczonych, i w Niemczech czy Polsce, jak to zobaczyć można u cytowanego wcześniej Garlickiego - swoje posłannictwo widzieli przede wszystkim w obalaniu stereotypowych wyobrażeń i przesądów o innych rasach czy narodach. Jak się wydaje, zaprzeczanie stereotypom nie prowadzi jednak do ich obalenia. Stereotypy o obcych i autostereotypy narodowe nie istnieją również w oderwaniu od sąsiadów - mamy tu do czynienia $z$ mechanizmem znanym $z$ psychologii społecznej, opisywanym przez Floriana Znanieckiego jako fenomen jaźni odzwierciedlonej: zdanie o sobie samym za każdym razem zależne jest od zdania innych $^{18}$. Badacze poststrukturalistyczni wrócili do tego poglądu, wskazując na interkulturalny aspekt powstawania tożsamości, która stanowi produkt interakcji i wymiany $z$ innymi. Wolno więc powiedzieć: autostereotyp tworzy się każdorazowo $\mathrm{w}$ powiązaniu $\mathrm{z}$ obcymi stereotypami, a stereotyp obcego $-\mathrm{z}$ naszych własnych wyobrażeń o sobie ${ }^{19}$.

Można zatem przyjąć za Miłoszem, „że Polacy wiedzą o Rosjanach to, co Rosjanie wiedzą o sobie samych, nie chcąc się do tego przyznać, i odwrotnie", a równocześnie trzeba zgodzić się, że taka przekazywana z pokolenia na pokolenie wiedza narodów jest bardzo niepewna i niełatwo poddaje się sprawdzianom. Nie oznacza to wszakże, iż zajmowanie się tą wiedzą staje się niepotrzebne lub bezsensowne. Dla rozwiania podobnych wątpliwości posłużmy się cytatem:

Rzeczywiście, bezsensowne byłoby ono [tj. zajmowanie się tą wiedza] wtedy, gdyby kulturę uznać się dało za zbiór pozytywnych rzeczy i czynów, która tę drugą kulturę, kulturę przesądów, mogłaby obiektywnie krytykować i empirycznie obalić. Tak jednak nie jest, a nawet gdyby tak się działo, niczego by to nie zmieniło, ponieważ ciagle jeszcze mielibyśmy do czynienia $z$ faktem, że kultury, jako hermeneutyczne akumulatory i maszyny o sprzężeniach zwrotnych, niewiele troszczą się o to, co pracowici historycy i faktografowie wyciagaja $z$ archiwów. A to dlatego, iż przesądy są - jako konceptualizacje siebie i innych - fenomenami dla każdej kultury centralnymi oraz czynnikami jej autorefleksji prowadzonej od wewnątrz i z zewnątrz ${ }^{20}$.

Frapujące w przesądach - przede wszystkim w tych interkulturalnych - jest to, że nie chodzi w nich o fakty, lecz o projekty, tzn. o kulturę w sensie interaktywnym. Albo dokładniej, że kultura tworzy się

18 F. Znaniecki, Prawa psychologii społecznej. Przeł. J. Radzicki. Warszawa 1991 (wyd. 1: Warszawa 1926).

19 Zob. A. As s ma n n, H. Fri e s e, wstęp w zb.: Identitäten. Erinnerung. Geschichte. T. 3. Hrsg. ... Frankfurt am Main 1998, s. 12.

20 A. A. Hansen-Löve, Zur Kritik der Vorurteilskraft. Russlandbilder. „Transit” 1999 (z. 16), s. 167. 
również z tych projekcji i ich sprzeczności, które ją trawią; zwraca się do innego, obcego, tylko po to, by czegoś w sobie samej nie dostrzec, i do swojego, by nie musieć widzieć cudzego ${ }^{21}$.

To bezwzględne obnażenie mechanizmu kultury nie powinno nas w żadnym wypadku skłaniać do jakiegoś zrezygnowanego cynizmu. Kultury nie są tylko wielkimi, anonimowymi tworami, rządzacymi się prawami długiego trwania i rozwijającymi się według niedostrzegalnego gołym okiem planu. Właśnie interaktywny charakter stereotypu powoduje, że tożsamość uczynić nam wolno obiektem nieustannych dwu-, a nawet wielostronnych interkulturalnych „pertraktacji”, nie pozwalając tym samym, by nasze wyobrażenia o sobie i innych za bardzo skostniały. Również literaturoznawstwo może w tym procesie uczestniczyć, polska literatura zaś dostarcza ku temu wiele okazji.

\section{Eseista i jego bohaterowie}

W pierwszej części Rosji podmiot eseju przypomina auktorialnego narratora dzieła epickiego, opowiadającego o dwóch bohaterach zbiorowych, Polakach i Rosjanach. Chodzi przede wszystkim o relacje między tymi dwoma narodami w XIX wieku. Wśród Rosjan Miłosz wyróżnia dwie grupy: tych, którzy popierają carską Rosję i służą jej, oraz rewolucjonistów, którzy pragną zniszczyć jej polityczny system. Stosunki między Polakami a pierwszą z wymienionych grup Rosjan opisywane są w następujący sposób:

Czuli s i ę [Polacy] wyżsi przez swoją tradycję, swój katolicki kodeks moralny, swoją przynależność do Zachodu. Policzk ow ał ich jednak jakiś ołowiany spokój na dnie charakteru Rosjan, ich cierpliwość, niewzruszoność, skrajność w ideałach, niedostępna dla ludzi myślowego kompromisu, i dlatego u pokarzała pamięć klęski. Dla Rosjan polski konwencjonalny obyczaj dygów, uśmiechów, grzeczności i pochlebstw był pustą formą, a tym samym fałszem. Ładowali w siebie przekon a ni e, że są wyżsi od powierzchownych, płytkich i motylkowatych, z ich drażliwym honorem i skłonnością do wypalania się w heroicznych a bezsensownych porywach. Dość przenikliwi, żeby rozróżnić starszą kulturalną formację, bolejący nad swoją niższością wobec wszystkiego, co zachodnie, z nieczystym sumieniem sług autokracji, zdawali sobie sprawe, czemu w powietrzu unosi się nie wymówione słowo: barbarzyńcy. Fas cynowało ich to właśnie, co ich odpychało: poetyczność, ironia, lekkość, łaciński obrządek. [M 151; podkreśl. M. Z.]

Miłosz w obu przypadkach przedstawia swoich bohaterów $\mathrm{z}$ wewnętrznej perspektywy ich kultury, posługując się przy tym mową pozornie zależną. Uwidocznia się to przede wszystkim w emocjach wyrażanych przez strony. Mowa pozornie zależna została uznana przez Romana Jakobsona za środek artystyczny typowy dla stylu realistycznego ${ }^{22}$; świadczy ona o chęci wyrównania pozycji bohaterów. Równowaga między nimi tworzy się np. dzięki temu, że wykreowany tu obraz jednych jest lustrzanym odbiciem drugich. Polakom jakby brakuje właśnie tego, czego Rosjanie zdaja się mieć wręcz w nadmiarze, i na odwrót. Pretensja, okazywana

$21 \quad$ Ibidem, s. 132.

22 R. Jakobs o n, Über den Realismus in der Kunst (1921). W zb.: Russischer Formalismus: Texte zur allgemeinen Literaturtheorie und zur Theorie der Prosa. Hrsg. J. S tri e d t e r. München 1994. 
przeciwnej stronie, spełnia więc funkcję kompensacyjną: ma wyrównać jakiś kompleks niższości, wynikający z dobrze uświadomionych własnych deficytów. Scysja między oponentami rozwinęła się zaś na tle dawnej i nowszej politycznej rywalizacji.

Także punkt widzenia Rosjan - wrogów Imperium - opisywany jest $z$ ich wewnętrznej perspektywy:

Rewolucjoniści polscy i rosyjscy walczący z caratem powinni byli być braćmi. Niezależnie jednak od tego, co mówią dzisiaj podręczniki, trwałe przymierze pomiędzy tymi ludźmi, na równi ofiarnymi i na równi wykształconymi, dzięki swemu pochodzeniu z klasy oświeconej, utrudniała incompatibility of temper, czyli różność historycznych formacji. Najbardziej nawet radykalni spośród Polaków mieli wiele wewnętrznych oporów, bo k o chali przeszłość i dlatego, nieraz podświadomie, traktowali rewolucję jako środek rozciągnięcia na całą ludność dawnych parlamentarnych przywilejów szlachty, a nie jako początek czegoś, co nie istniało nigdy. [...] Rosjan natomiast zaprzątały zupełnie inne kłopoty. Z g ory c za mogli rozmyślać o swoim suwerennym, i jak jeszcze, państwie. Nic nie hamowało ich marzeń, ani religia, ta najpewniejsza podpora tronu, ani dawne struktury ustrojowe, których nie kochali, bo równały się tylko uciskowi i wszechmocy carów. Zwracali się wyłącznie w przyszłość, chcieli burzyć i na ziemi zmienionej w tabula rasa zacząć budować od nowa. [M 152-153; podkreśl. M. Z.]

Rosjanie są według Miłosza bliżsi Polakom niż uwielbiani przez tych ostatnich Francuzi, ponieważ struktura społeczna ich kraju bardziej przypomina Rosję od krajów zachodnich. Nawiasem mówiąc, jest to u Miłosza jedyne tertium comparationis obu narodów.

Sposób, w jaki opisuje się w przytoczonych ostatnio cytatach wzajemny stosunek Polaków i Rosjan, pozwala przypuszczać, że oba te narody żyją w wyjątkowo trudnym sąsiedztwie, polityka zaś czyni $z$ nich często wrogów lub przynajmniej przeciwników. Wydają się oni jednak nawzajem dobrze znać. Poglądy prezentowane w przywołanych cytatach są przecież wyrazem żywych kontaktów zainicjowanych w XIX wieku w warunkach, które wszakże trudno uważać za korzystne. Skrótowość, jaka charakteryzuje ujęcie Miłosza, prowadzi w sposób nieunikniony do uproszczeń, jednak związek z rzeczywistością historyczną nie zostaje tu przerwany. Obrazy Polaków i Rosjan można więc nazwać streotypami w znaczeniu lippmannowskim.

Realistyczne nacechowanie tekstu (w sensie, jaki temu terminowi przypisuje współczesne literaturoznawstwo) pozwala oczekiwać, że oprócz tych dwóch skrajnych i sprzecznych punktów widzenia pojawi się jeszcze trzeci, pojednawczy ${ }^{23}$. Zadanie to wypełnia, przynajmniej częściowo, głos narratora: jego sympatia jest wprawdzie jednoznacznie po stronie polskiego systemu politycznego, ale nie samych Polaków, ponieważ ci ostatni (czy też ich historyczna klasa wyższa) nie okazali się skłonni zrezygnować z części przywilejów, by zachować swój system polityczny i niepodległość: „grzechem była trwająca stulecia dyskusja o własnych grzechach und Realität. Hrsg. K. O e hl e r. Tübingen 1984, s. 503) opisują ten charakterystyczny dla realizmu środek stylistyczny w następujący sposób: „Oprócz tego, że tekst realistyczny dzieli się na dwa komunikaty o jednym i tym samym wydarzeniu, pojawia się między nimi jeszcze trzeci komunikat, który spełnia funkcje medialne między dwoma pozostałymi. [...] Zasadniczo można stwierdzić, że w świetle realistycznej mimesis tylko ten znak odpowiada sytuacji referencjalnej lub posiada cechy głębokiej prawdy, który zdolny jest odgrywać rolę pośrednika między dwoma diametralnie przeciwnymi znakami”. 
- w literaturze, na sejmikach, w parlamencie - z której prawie nigdy nic nie wynikało w praktyce" (M 148).

Realizm współistnieje u Miłosza jednak z z u pełni e in n y m postrzeganiem Rosjan i Rosji. Poeta opiera się tutaj głównie na obrazach Rosji znanych z dzieł literackich, zwłaszcza z dzieł Mickiewicza.

\section{Pustka na Wschodzie}

Pierwszy ważny passus na ten temat dotyczy u Miłosza dość odległej przeszłości:

Przede wszystkim wiek XVI i XVII. Niełatwo sobie dzisiaj uświadomić, że język polski, jako język klasy dominującej, a więc oświeconej, oznaczał wykwint i ogładę daleko na wschód, w Połocku czy Kijowie. Moskwa byli to barbarzyńcy, z którymi toczono wojny na peryferiach jak z Tatarami, i nie interesowano się nimi szczególnie - w literaturze polskiej częściej można spotkać charakterystyki Węgrów, Niemców, Francuzów i Włochów niż wzmianki o poddanych cara. Odnotowywano ich niezrozumiała pokorę wobec despotyzmu władców, skłonność do łamania przyrzeczeń, podstępność i wykpiwano dzikość ich obyczajów (Francuzom z kolei dzikie wydawały się obyczaje Sarmacji). Ruch idei, kolonizacja ziem zarosłych puszczą czy stepem odbywały się z zachodu na wschód. Prawie wszystko, co ceniono - wzory rzemiosła, wzory architektury, piśmiennictwa, dyskusje humanizmu i Reformacji, przychodziło z Flandrii, z Niemiec, z Italii. Jeżeli silne były też zapożyczenia wschodnie, to, dzięki wielkiemu szlakowi handlowemu, z Turcji, zwłaszcza w strojach, uprzężach i odpowiadających im nazwach. Gdyż Moskwa, która powoli przekształcała się w Rosję, poza mniejszą czy większą potęga nie reprezentowała nic atrakcyjnego. Czym dla Polski jako kulturalne piętno był wiek XVI i XVII, dla Rosji miał stać się dopiero wiek XIX. Z tego też okresu pustki na Wschodzie pochodzi u Polaków pojęcie Rosji jako czegoś z zewnątrzét, poza orbita świata. Swoją przegraną przyjęli następnie ze zdumieniem, tak jak przyjęliby podbój przez Tatarów; jeżeli to miało sens, mogło oznaczać tylko karę za grzechy. [M 147-148; podkreśl. M. Z.]

Wolno byłoby sądzić, że Polacy na skutek bolesnych doświadczeń pożegnali wyobrażenia Rosji jako owego „wielkiego Nic”. Tak się jednak nie stało i będzie jeszcze o tym mowa. Ta idea nie jest zresztą wymysłem Polaków, lecz stanowi część ogólnoeuropejskiego przesądu na temat tego kraju i również gdzie indziej długo zachowała atrakcyjność.

Już najstarsze wyobrażenia Polaków dotyczące mieszkańców Rusi nawiązują do szeroko rozprzestrzenionego w Europie obrazu Rosjan jako schizmatyków. Gall Anonim stwierdzał w swojej kronice, że wschodnie i północne granice Polski stanowią jednocześnie granice prawdziwej (tj. katolickiej) wiary, nie szczędził przy tym przykrych słów jej wschodnim sąsiadom ${ }^{25}$. Także wtedy musiała więc zaznaczyć się rywalizacja, w której Polska przypisywała sobie pozycję ultima Thule chrześcijańskiej Europy. Postawę tę, jak się zdaje, prezentowano jednak w oficjalnych stosunkach z Zachodem, przede wszystkim zaś w listach do Watykanu. W stosunkach dwustronnych retoryki tej raczej nie używano, a we wczesnym okresie piastowskim książęta chętnie wybierali sobie żony pochodzące z Rusi, co można uznać za dowód, iż stosunki „domowe” między panującymi były raczej dobre.

24 Sformułowanie „Z zewnątrz” zostało podkreślone również przez Miłosza.

25 Zob. A. Semiańczuk, H. Semiańczuk, Oblicza Wschodu $w$ dziejopisarstwie polskim do końca XVI wieku. W zb.: Oblicza Wschodu w kulturze polskiej. Red. G. Kotlarski, M. Figura. Poznań 1999, s. 24. 
Rywalizacja między Polską a Rosją zyskuje inny ciężar gatunkowy w wieku XVI, gdy Rosja staje się na tyle znacząca siłą, że w Watykanie zaczyna się myśleć o wciągnięciu jej do antytureckiej ligi. Wtedy to dyplomacja próbuje szczególnie intensywnie propagować autostereotyp Polaków jako antemurale christianitatis, skierowany przeciwko Turkom i Tatarom, lecz również przeciwko moskiewskiemu państwu. Celem politycznym tych działań było zachowanie przewodniej roli w tej części Europy. W drugiej połowie XVI wieku w Europie można mówić o dwóch przeciwstawnych stanowiskach wobec Rosji: pierwsze, reprezentowane głównie przez Francję i wspierane przez polską dyplomację, widzi w Rosji przede wszystkim wroga chrześcijaństwa, a drugie, reprezentowane przez miasto-państwo Wenecję, widzi w porozumieniu $z$ tym państwem warunek skutecznej walki $z$ Turcją ${ }^{26}$. Nie wolno przy tym zapominać, że polska szlachta znajdowała się, począwszy od drugiej połowy XVI wieku aż po koniec wojen szwedzkich w wieku XVII, pod silnym wpływem kalwinizmu (nie mówiąc już o luterańskiej ludności miast, która pod względem etnicznym w dużej części nie była polska). W związku z tym szlachta polska mogła dla ówczesnej dyplomacji watykańskiej przedstawiać o wiele groźniejszy rodzaj schizmatyków niż mieszkańcy Rosji. Jednak nawet reformacja nie zmieniła europejskich wyobrażeń o Polsce jako antemurale christianitatis ${ }^{27}$, chęć zaś zachowania status quo w Europie wiązała się $\mathrm{z}$ podtrzymywaniem wśród Polaków uprzedzenia do Rosji i jej religii. Z drugiej strony, szczególnie po unii brzeskiej wpływy prawosławia na katolicyzm we wschodniej Polsce wzrosły, gdyż samo zachowanie liturgii i hierarchii dawnej cerkwi musiało prowadzić do jakichś interferencji. Wpływy takie zaznaczać się mogły jednak tylko nieoficjalnie, w kulturze wysokiej natomiast dostrzega się je rzadziej, ponieważ szlachta często przechodziła na katolicyzm, a Kościół unicki powoli stawał się ludowy.

Jak tęsknoty polityczne są w stanie oddziaływać na obraz innych narodów, da się prześledzić na przykładzie kroniki Jana Długosza (Roczniki, czyli kroniki sławnego Królestwa Polskiego). Jest to, prawdopodobnie, pierwsze dzieło annalistyki europejskiej, w którym utrwalono ważne elementy rosyjskiego stereotypu. Ponieważ Długosz popierał polską ekspansję na Wschód, twierdził m.in., że Rus, praojciec Rusi, był wnukiem Lecha, a nie, jak we wcześniejszej tradycji, jego bratem, i że Kijów został założony przez polskiego księcia ${ }^{28}$. Trudno powiedzieć, czy kronika Długosza w jakikolwiek sposób wpłynęła na postrzeganie Rosji w Europie. Zarów-

Zob. J. Tazbir, Polskie przedmurze chrześcijańskiej Europy. Mity a rzeczywistość historyczna. Warszawa 1987, passim.

27 Zob. D. Gro h, Russland im Blick Europas. Frankfurt am Main 1988, s. 31 (wyd. 1 ukazało się pt. Russland und das Selbstverständnis Europas. Ein Beitrag zur europäischen Geschichte 〈Heidelberg 1960)). Oto fragment podsumowania Groha (ibidem, s. 34) dotyczacy dzieła Sully'ego, ministra Henryka IV, Association ou république très chrétienne: „Moskale są barbarzyńcami, nie mogą współpracować z ludami cywilizowanymi. [...] Pozycja Polski jako przedmurza pojawia się konsekwentnie jako obrona nie tylko przed Turkami i Tatarami, lecz także Rosja”.

28 Zob. A. Kija s, Moskwa $w$ relacjach polskich XVI i pierwszej połowy XVII wieku. W zb.: Oblicza Wschodu $w$ kulturze polskiej. Warto przytoczyć następujące wnioski autora na temat stosunku Długosza do państwa moskiewskiego: „Podziw dla jego [tj. Długosza] dokonań nie oznaczał jednak sympatii dla Rusinów. Ponadto uważał, że są chytrzy i przewrotni, jak również chwiejni i fałszywi. Względy religijne powodowały, że polski autor daleki był od tolerancji i szacunku dla kulturowych osobliwości Rusinów, szczególnie zaś dla prawosławia. Wyznawców tej konfesji obarczał odpowie- 
no on, jak i poeci polskiego renesansu: Mikołaj Rej (Zwierciadło, albo kształt, $w$ którym każdy stan snadnie się może swym sprawom jako we zwierciadle przypatrzyć 〈1568〉) i Jan Kochanowski (Jezda do Moskwy, w wydaniu drugim nazwana Wtargnienie do Moskwy), kronikarz Maciej z Miechowa (Tractatus de duabus Sarmatis asiatiana et europiana in eis $\langle 1517\rangle$ ) i protestant Jan Łasicki (De Russorum, Moscovitarum et Tatarorum religione, sacrificiis, nuptiarum et funerum ritu et diversis scriptoribus 〈Spirae 1582〉) nigdy nie podróżowali do miejsc, które opisywali. Pierwsze polskie relacje świadków (np. Pawła Paczowskiego Kolęda moskiewska. Tojest wojny moskiewskiej przyczyny stuszne i Samuela Maskiewicza Dyariusz) powstały w latach 1609 i 1611, a więc po polskiej wyprawie na Moskwę. Wnosza one liczne interesujące detale, nie mogły jednak w sposób znaczący wpłynąć na europejski stereotyp w myśleniu na temat Rosji, gdyż ten był już od pewnego czasu ustalony. Najwięcej zdziałali na tym polu prawdopodobnie Sigismund von Herberstein, dwukrotny poseł cesarski do Moskwy (Rerum moscovitiaricum commentair $^{29}$ ) oraz kupcy angielscy. Chociaż rekonstrukcja wzajemnego wpływania na siebie różnych relacji o Rosji z tamtego okresu byłaby dzisiaj trudna, można jednak stwierdzić, że stereotypy polski i europejski we wszystkich istotnych punktach były bardzo podobne ${ }^{30}$.

\section{Ustęp Mickiewicza i Rosja Miłosza}

Jak wiadomo, Dziady, część III i składający się z sześciu mniejszych utworów Ustęp powstały jako odpowiedź na stłumienie powstania listopadowego. Negatywna reakcja Europy na postępowanie rosyjskich władz w Polsce skłoniła najpierw poetów rosyjskich Aleksandra Puszkina, Wasilija Żukowskiego i Aleksieja Chomiakowa do wspólnej publikacji, wspierającej politykę cara. Przede wszystkim dwa wiersze Puszkina z tej publikacji, Oszczercom Rosji i Rocznica Borodina, musiały osobiście dotknąć Mickiewicza, który poznał ich autora raczej jako ostrego krytyka caratu. Według Miłosza „poemat Mickiewicza stanowi s u m m ę polskiego nastawienia do Rosji” (M 150). O ponadepokowym znaczeniu tego dzieła dla Polaków mówi chociażby fakt, że wydarzenia roku 1968 zaczęły się właśnie od Dejmkowskiej inscenizacji Dziadów.

Ustęp jest utworem na wskroś politycznym, skierowanym zresztą nie tylko do rodaków i czytelników zachodnich, lecz również do wybitnych rosyjskich literatów, przede wszystkim do Puszkina. Zdaniem niektórych badaczy, Puszkin podjął to wyzwanie w poemacie Jeździec miedziany, będącym odpowiedzią na wiersz Mickiewicza Pomnik Piotra Pierwszego z Ustępu.

dzialnością za nieszczęścia, jakich doznał świat chrześcijański w konfrontacji z Turkami” (ibidem, s. 56).

29 Dzieło powstało w latach 1517-1549. O Herbersteinie i innych sprawozdaniach z Moskwy tego czasu pisze M. T. P o e („A People Born to Slavery”. Russia in Early Modern European Ethnography, 1476-1748. Ithaca-London 2000).

30 Problemem prawdziwości obrazu Rosji w opisach podróży w omawianym okresie zajmują się G. Scheidegger (Perverses Abendland - barbarisches Russland. Begegnungen des 16. und 17. Jahrhunderts im Schatten kultureller Missverständnisse (Zürich 1993〉) i P o e (op. cit.). 
Zauważmy, że struktura komunikacyjna Rosji Miłosza przypomina po części Ustęp Mickiewicza: adresatem explicite jest tutaj także Zachód, a adresatami implicite - Polacy i Rosjanie. Miłosz nie zwraca się bezpośrednio do „przyjaciół Moskali”, jednak zaczepny wobec Rosjan charakter jego eseju wydaje się dosyć oczywisty.

O sukcesie tego „Okrutnego pamfletu [...]” (M 149), jak Miłosz nazywa Ustęp, zadecydowała zarówno olśniewająca forma literacka, która Rolf Fieguth definiuje „jako udaną wędrówkę po niebezpiecznym obszarze granicznym między wysublimowaną poezją, wczesnorealistyczną satyra, metafizycznym lotem w przestworzach i - natchnioną poezją nienawiści”"31, jak i fakt, że Miłosz znakomicie trafił w oczekiwania swoich rodaków.

W Ustępie znajdziemy całe spektrum satyrycznych, niezmiernie złośliwych obrazków Imperium Rosyjskiego i jego stolicy ${ }^{32}$. Mickiewicz nie stara się tu wcale wykreować obrazu obiektywnego. Obiektywizm nie dałby się pogodzić $z$ celem, który postawił sobie poeta w stosunku do adresatów tego utworu. Historyczne wydarzenia, do których odnoszą się Dziady, były jeszcze zbyt świeże, a ich skutki nie do końca przewidywalne. W dziele Mickiewicza narodowa depresja zmienia się $\mathrm{w}$ - werbalną - agresję. $Z$ punktu widzenia dzisiejszej psychoanalizy postępowanie takie jest wzorcowe i należy je pochwalić, jednak czytelnicy tego utworu poza Polską często go nie rozumieli ${ }^{33}$. Twierdzenie Fiegutha, według którego Mickiewiczowi brakuje po prostu współczucia wobec Rosjan, nie wydaje się wszakże uzasadnione ${ }^{34}$.

31 R. Fieguth, Mickiewiczs Russland - anhand „der Sonette” und „des Epischen Abstands” von „Dziady III”. „Wiener Slawistischer Almanach” t. 44 (1997): „Mein Russland”. Beiträge der gleichnamigen Tagung vom 4.-6. März 1996 in München, s. 217.

32 Zob. przegląd problematyki Ustępu u Z. S t e fa n ow s k i ej (Rosja w „Ustępie” III części „Dziadów”. W zb.: „W krainie pamiatek”. Prace ofiarowane profesorowi Bogdanowi Zakrzewskiemu w osiemdziesiąta rocznice urodzin. Red. J. Kolbuszewski. Wrocław 1996). Zob. też Fie guth, op. cit. M. Zi elińs ka, „Ustęp” III części „Dziadów” i jego rosyjskie konteksty. W: Polacy, Rosjanie, romantyzm. Warszawa 1998.

33 Można się dziwić, że utwór ten, liczący sobie już prawie 170 lat, praktycznie do dzisiejszego dnia wzbudza tak silne emocje zarówno u Polaków, Rosjan, jak i u czytelników zachodnich. Jest to o tyle zrozumiałe, że zajęcie neutralnej pozycji wobec Rosji było w Europie najpóźniej od rewolucji francuskiej praktycznie niemożliwe, Ustęp z łatwością dawał się także odnieść do dalszych wydarzeń. Za charakterystyczną dla tego dyskursu należy uznać wypowiedź Fiegutha (op. cit., s. 230): „Zwracająca się przeciwko rosyjskiemu państwu i przez to państwo uformowanemu człowiekowi gorycz, wzbierająca w wielu fragmentach Ustępu, przypomina nieco starszej generacji slawistów bezwarunkowe potępienie systemu sowieckiego i sowieckiego człowieka, które wielokrotnie formułowane było przez uwolnione ofiary tego systemu lub przez określone grupy dysydentów i kierowane do Zachodu jako ostrzeżenie”. To rzecz zrozumiała, że obraz okupanta czy nawet kata, który tworzy sobie ofiara, nie jest obiektywny. Czegoś innego od ofiary wymagać zresztą się nie powinno. Zmiana może tu nastąpić dopiero, gdy ofiara przestanie być ofiarą.

34 Obraz Rosji u Mickiewicza jest dla Fi e g u th a (ibidem, s. 217): „trudny do zniesienia, szczególnie gdy podyktowany jest przez zażartą nienawiść i narodową małostkowość oraz gdy ta widzi tylko polskie, a nie rosyjskie cierpienie pod władzą despotyzmu”. To twierdzenie wynika jednak z nieporozumienia. W pełnym sprzeczności stosunku Mickiewicza do Rosji nie brakuje bowiem i współczucia. Mickiewicz widzi we wszystkich Rosjanach ofiary carskiego systemu, dlatego też irytują go przyjaciele poeci, którzy z dumą wskazują na osiągnięcia Imperium, jak to jest w przypadku autorów tomu Na wzięcie Warszawy. Wersy z utworu Do przyjaciół Moskali: „Kto z was podniesie skarge - dla mnie jego skarga, / Będzie jak psa szczekanie, który tak się wdroży / Do cierpliwie i długo noszonej obroży / Że w końcu gotów kąsać rękę, co ją targa” (w: A. Mi c ki e w i c z, Dzieła. 
$\mathrm{Z}$ owego niezmiernie bogatego materiału, który znajduje się w Ustępie Mickiewicza, Miłosz wybrał stosunkowo krótki fragment z Drogi do Rosji:

Spotykam ludzi - z rozrosłymi barki, / Z piersią szeroką, z otyłymi karki; / Jako zwierzęta i drzewa Północy, / Pełni czerstwości i zdrowia, i mocy. / Lecz twarz każdego jest jak ich kraina, / Pusta, otwarta i dzika równina; / I z ich serc, jako wulkanów podziemnych, / Jeszcze nie przeszedł ogień aż do twarzy, / Ani się w ustach rozognionych żarzy, / Ani zastyga w czoła zmarszczkach ciemnych - / Jak w twarzach ludzi Wschodu i Zachodu, / Przez które przeszło tyle po kolei / Podań i zdarzeń, żalów i nadziei, / Że każda twarz jest pomnikiem narodu. / Tu oczy ludzi jak miasta tej ziemi, / Wielkie i czyste - i nigdy zgiełk duszy / Niezwykłym rzutem źrenic nie poruszy: / Nigdy ich długa żałość nie zaciemni. / Z daleka patrząc - wspaniałe, przecudne; / Wszedłszy do środka - puste i bezludne. / Ciało tych ludzi, jak gruba tkanica, / W której zimuje dusza gąsienica, / Nim sobie piersi do lotu wyrobi, / Skrzydła wyprzędzie, wytcze i ozdobi; / Ale gdy słońce wolności zaświeci, / Jakiż z powłoki tej owad wyleci? [M 149-150] $]^{35}$

W przeszłości twierdzono często, że utwór Mickiewicza zawdzięcza swój sukces głębokiej wiedzy, która autor zebrał podczas zesłania w Rosji ${ }^{36}$. Rolf Fieguth zwrócił uwage na cechy, jakie łączą Ustęp z reportażem i szkicem fizjologicznym. Niewątpliwie pokrewieństwa te przyczyniły się do tego, że Drogę do Rosji uznawano za relację naocznego świadka, prawie za sprawozdanie $z$ własnej podróży Mickiewicza na wygnanie. Dziś jednak przeważa wśród badaczy przekonanie, iż poeta stworzył tu raczej syntezę, na którą składają się różne literackie topoi, znane $z$ innych przedstawień Rosji ${ }^{37}$. Jak pokazał Andrzej Kępiński, obraz rosyjskiego chłopa w cytowanym przez Miłosza fragmencie Drogi do Rosji zbieżny jest z opisem dobrego i łagodnego Słowianina, pozostawionym przez Mickiewicza w jego prelekcjach paryskich $^{38}$. Portret ten, któremu zwykle towarzyszyło przekonanie o „naturalnej” skłonności Słowian do pokojowej egzystencji związanej z rolnictwem, nie opiera się, oczywiście, również na osobistych obserwacjach Mickiewicza, lecz na jego lekturach, od Johanna Gottfrieda Herdera począwszy, a na Kazimierzu Brodzińskim skoń-

T. 3. Warszawa 1955, s. 308), tak dla Fiegutha gorszące, nie świadczą o braku współczucia. Drażniąca (w sposób przez Mickiewicza zamierzony) jest tutaj przede wszystkim podwójność komunikatu, w którym współczucie i deklaracja wspólnoty, wyrażające się w apostrofie Do przyjaciót Moskali, mieszają się z potężną dawką nienawiści i odrzucenia.

35 Przytaczam ten cytat wiernie za Miłoszem, który nie zachował Mickiewiczowskiej formy wierszowej oraz w kilku miejscach popełnił drobne omyłki w stosunku do oryginału.

36 Zob. następujące stwierdzenie A. Kę piń sk i e go (Lach i Moskal. Z dziejów stereotypu. Warszawa-Kraków 1990, s. 79): „Fakt, iż z polskich romantyków [Mickiewicz] bodaj najlepiej poznał Rosję, czyni ten wzorzec wiarygodnym, uznanie zaś poety za "wieszcza nad wieszczami» sprawia, iż Mickiewiczowska wizja Rosji ma dla potocznej świadomości Polaków moc obowiązująca i stanowi podstawowy rezerwuar stereotypów oraz wzór dla niezliczonej rzeszy naśladowców [...]".

37 Zielińska (op. cit., s. 75) tak o tym pisze: „autor zamierzał świadomie stworzyć syntetyczną wizję Rosji, wykorzystując wszelkie dostępne mu doświadczenia i wiadomości - wyselekcjonowane i ułożone w określonym porządku".

38 Kę pińs ki, op. cit., s. 102. Autor powołuje się na następujący passus pojawiający się u A. Mickiewicza (Literatura słowiańska. Kurs pierwszy. Pierwsze pótrocze. W: Dzieła, t. 8 〈przeł. J. Płoszewski〉, s. 58): „Ma wzrost wysoki, silną budowę ciała, długie nogi o stopach raczej silnych niż wielkich. Ramiona jego i barki są rozwinięte nadmiernie. Pierś ma również szeroką, ramiona mocne, rękę kształtną, lecz krzepką, z muskułami o niezwykłej sile. Jest to lud widocznie przeznaczony do rolnictwa, do pracy, do życia wiejskiego. [...] oczy piękne, szeroko otwarte, ale nieco zaklęsłe i w stosunku do całej głowy wydają się za małe”. 
czywszy. Negatywne aspekty portretu Rosjanina pochodzą natomiast z Pierwszego listu filozoficznego Piotra Czaadajewa. Wacław Lednicki wskazał odpowiednie miejsce $^{39}$ :

Uważam nawet, że w naszym spojrzeniu jest coś dziwnie nieokreślonego, chłodnego, niepewnego, przypominającego oblicze narodów stojących na najniższych szczeblach drabiny społecznej. W obcych krajach, zwłaszcza na Południu, gdzie fizjonomie są tak ożywione i wyraziste, tyle razy porównywałem twarze moich rodaków i tamtejszych mieszkańców, i byłem zaskoczony brakiem wyrazistości na naszych twarzach ${ }^{40}$

Takie frapujące podobieństwa uznał Lednicki za dowód bezpośredniego wpływu, jaki Czaadajew miał wywrzeć na Mickiewicza. Chociaż nie istnieją dowody na ich osobiste kontakty, to jednak wiadomo, że obracali się oni w tych samych kręgach ${ }^{41}$.

Trzeba wszakże stwierdzić, iż Mickiewicz sięga tutaj do starego europejskiego toposu - wspomnianego zresztą już przez Miłosza - każącego widzieć w Rosji „wielkie Nic”. Topos ten przeżył w epoce oświecenia ogromny renesans, szczególnie kiedy Gottfried Wilhelm Leibniz przeformułował jego znaczenie, używając przy tym charakterystycznych dla tej epoki pojęć. Kierowany przekonaniem o głębokim kryzysie kultury europejskiej, uznał on ową „nicość” Rosji za cechę pozytywną: jeżeli bowiem Rosja jest „niczym”, nic w niej nie może być złe. Jako tabula rasa stanowiła więc Rosja dla Leibniza stosownego kandydata do wielkiego eksperymentu mającego na celu stworzenie idealnego (europejskiego) państwa. Leibniz marzył o aliansie $z$ Piotrem Wielkim (który przede wszystkim na początku przedstawiał się jako władca oświecony), aby razem $z$ nim sprawować absolutną władzę rozumu $\mathrm{w}$ Rosji ${ }^{42}$. Ten dziwaczny pomysł, każący filozofom zawierać alianse $z$ monarchami

39 W. Le d n i c ki: O „Jeźdźcu miedzianym”. W: A. P u s z k i n, Jeździec miedziany. Opowieść petersburska. Przeł. J. Tu w i m. Warszawa 1932; Pushkin’s „Bronze Horseman”. The Story of a Masterpiece. With an Appendix Including, in English, Mickiewicz's „Digression”, Pushkin's „Bronze Horseman", and other Poems. Berkeley, Calif., 1955; Russia, Poland and the West. Essays in Literary and Cultural History. London 1954, zwłaszcza s. 21-62.

$40 \quad$ P. C z a a d a j e w, Pierwszy list filozoficzny (fragmenty). W zb.: Dusza polska i rosyjska (od Adama Mickiewicza i Aleksandra Puszkina do Czesława Miłosza i Aleksandra Sołżenicyna). Materiały do „katalogu” wzajemnych uprzedzeń Polaków i Rosjan. Red. A. d e La za ri. Warszawa 2004, s. 43. Jest rzeczą znaczącą, że Czaadajew porównuje ekspresję uczuć w twarzach Rosjan z twarzami narodów Europy Południowej. Paralela między ekspresywnością rosyjską a tą ludów skandynawskich lub innych germańskich musiałaby go doprowadzić do odmiennych wniosków.

41 Czaadajew wycofał się z kręgów dekabrystów jeszcze przed przybyciem Mickiewicza do Rosji, fakt ten nie wyklucza jednak ich osobistych kontaktów. Możliwe jest również, że Mickiewicz zapoznał się z ideami Czaadajewa poprzez rozmowy z innymi dekabrystami. Pierwszy list filozoficzny został napisany w r. 1829, a opublikowany w 1837 roku.

42 Leibniz głównie próbował nakłonić Piotra I do założenia w Petersburgu akademii. Opisując tę ideę, Gro h (op. cit., s. 49) zwraca uwage przede wszystkim na paralele między absolutystyczną formą rządów a modelem niemieckiego filozofa: „Jest uderzające, jak bardzo [model ten] różni się od wszystkich istniejących już "akademii" tamtego czasu. Istotą tej "akademii" okazuje się nie duchowa wymiana, lecz planowanie procesu wychowawczego commune bonum - związek historiozofii i planowania jest tu jasny. Miała ona być bardziej "urzędem planowania" niż towarzystwem uczonych, jak to było w przypadku Francji i Anglii”. Piotr I odrzucił jednak projekt filozofa: podobnie jak później Katarzyna Wielka, wolał realizować swoje pomysły sam. 
absolutnymi, powróci u filozofów oświecenia francuskiego, przede wszystkim u Voltaire’a i Denisa Diderota, którzy złożą swoje nadzieje u stóp Katarzyny Wielkiej.

Kontrowersja na temat Rosji, którą wzbudził Leibniz, nie była jakimś marginalnym zjawiskiem, lecz przygrywką do długiej i zawiłej debaty o przyszłości Europy. Dieter Groh pisze o tym w następujący sposób: „Leibniz antycypuje perspektywę, z której prorocy upadku Europy w wieku XIX czynić będą stosunek do Rosji tematem swoich historiozofii" 43 .

Pod wpływem rewolucji francuskiej powstały dwie opcje na temat Rosji: pierwsza, optymistyczna, widziała w tym państwie - podobnie jak Leibniz - ratunek dla europejskiej kultury; druga, pesymistyczna - główną przyczynę przepowiadanego upadku Europy. Konserwatywni obrońcy dawnego porządku należeli na ogół do grupy pesymistów, liberałowie natomiast do optymistów, zdarzały się jednak odstępstwa od tej zasady: porewolucyjnym pomysłodawca koncepcji Rosji jako ratunku dla Europy był wszak arcykonserwatywny Joseph de Maistre ${ }^{44}$. Karol Marks patrzył natomiast na Rosję bardzo krytycznie - a w najlepszym wypadku z dużą rezerwą ${ }^{45}$.

Centralna konstrukcja myślowa dysputy na temat przyszłości Europy, jej niejako „algorytm”, pochodzi od pesymistycznie nastawionego konserwatysty Alexisa de Tocqueville’a. Porównał on sytuację współczesnej sobie Europy do schyłkowej fazy Cesarstwa Rzymskiego. Ta tzw. wielka paralela implikowała, oczywiście, pytanie o koniec chrześcijaństwa i kazała szukać „nowych Germanów”46. Po rewolucji październikowej przeniesiono „wielką paralelę” na Związek Radziecki.

Mickiewicz, tworząc w Drodze do Rosji swój obraz tego kraju, najwięcej przejął prawdopodobnie od Czaadajewa, ten natomiast przywiózł części składowe tego obrazu ze swoich podróży po Europie. Francuscy konserwatyści zdążyli już bowiem wtedy przenicować Leibnizowskie pojęcie tabula rasa i uczynić je znowu negatywnym. Czaadajew powtarzał ich argumenty, nadając im mistrzowską formę literacką. Właśnie walory literackie jego dzieła usunęły w cień jego poprzedników. Podobnie jak Czaadajew postępował, również podziwiany przez Miłosza, Astolphe de Custine (M 167). Czaadajew, Mickiewicz, de Custine i wielu innych pracują z ruchomymi elementami dekoracji, które wymieniają między sobą Rosjanie i nie-Rosjanie, wielbiciele i wrogowie Rosji. Nie znaczy to, oczywiście, że swoją grę uprawiają oni „oficjalnie”, czasem nawet robią to nie do końca świadomie. Każdemu z autorów owych „wielkich” (i często olśniewających pod względem literackim) „syntez” chodzi o stworzenie przynajmniej pozorów, że jest ona dziełem naocznego świadka. Tylko w ten sposób przesąd może uzyskać status powszechnie obowiązującej prawdy: jeżeli wszyscy widzieli „na własne oczy” i prawie to samo pisza, to wnioski sa jasne. Można wszakże udowodnić, że żaden $z$ omawianych trzech autorów nie przekazał po prostu tego, co zobaczył. W prozie de Custine’a znajdziemy

$43 \quad$ Ibidem, s. 52.

44 Ibidem.

45 Zob. A. W ali cki, Marks i Engels o sprawie polskiej. Uwagi metodologiczne. W zb.: Powstanie listopadowe 1830-1831. Geneza, uwarunkowania, bilans, porównania. Red. J. Skowronek, M. Żmigrodzka. Wrocław 1983. - H. Fle is c h e r, Marx, Engels, der Zar und die Revolution. W zb.: Russen und Russland aus deutscher Sicht. 19. Jahrhundert. Von der Jahrhundertwende bis Zur Reichsgründung (1800-1871). Hrsg. M. Kelle r. Red. C. Pawlik. München 1991.

46 Groh, op. cit., s. 206 n. 
np. wiele cennych spostrzeżeń, jednak jego ogólny obraz Rosji bez wattpienia nie powstał podczas dwuipółmiesięcznej podróży po tym kraju. Podróż ta natomiast $\mathrm{z}$ pewnością pobudziła go do szukania wniosków u poprzedników, a talent literacki de Custine’a pozwolił mu zająć wśród znawców Rosji tak wyjątkową pozycję. Całe historiozoficzne tło de Custine’a pochodzi według Groha od francuskich tradycjonalistów, którzy tak silnie oddziałali również na Czaadajewa:

Wpływ tradycjonalistów na Czaadajewa jest udowodniony, a w Pierwszym liście filozoficznym można go dowieść nawet na poziomie pojedynczych sformułowań. Nie odgrywa więc większej roli, czy z kolei Czaadajew wpłynał czy nie [na de Custine’a]. Prawdopodobnie jest on zależny bezpośrednio od tradycjonalistów. Przemawia za tym ogólna tendencja książki i twierdzenie de Custine’a, że udał się do Rosji, aby zbierać tam argumenty przeciwko konstytucyjnej formie rządów we własnym kraju, powrócił jednak stamtąd jako jej zwolennik [...]. Za wpływem Czaadajewa przemawia jednak fakt, iż de Custine zestawił wszystkie dotyczące Rosji fragmenty $z$ [pism] tradycjonalistów w taki sam sposób jak Rosjanin ${ }^{47}$.

Dla Mickiewicza dar obserwacji jest równie mało, a może nawet jeszcze mniej, ważny niż dla jego poprzedników. Przesądy nie znaja granic, są ulubionym artykułem i importu, i eksportu. Aage A. Hansen-Löve tak pisze o regułach tej międzynarodowej wymiany:

Wyprodukowany na zewnątrz kraju, obcy obraz własnej kultury importowany jest $\mathrm{z}$ wielkim zapałem, tzn. na zewnątrz wyprodukowany, konsumowany jest wewnątrz. Umotywowane politycznie i tworzone przez stulecia wyobrażenie obcej Azji zostało przeniesione z barbarzyńców na Rosjan - niezależnie od tego, czy istniały do tego przesłanki czy nie. Decydujące było przy tym, że projekcje te były namiętnie przejmowane przez samych Rosjan, tzn. że asymilowali oni z zewnątrz obce projekcje, które stapiały się $\mathrm{z}$ autoportretem uczynionym na użytek domowy ${ }^{48}$.

Importowaniu przesądu stało na drodze narodowe tabu, dobrze słyszalne w słowach Puszkina: „Naturalnie, pogardzam moją ojczyzną od stóp do głów, ale drażni mnie, kiedy cudzoziemiec dzieli ze mną to uczucie" ${ }^{\text {"9 }}$. W następstwie tego bardzo często przyswajamy sobie cudze zdanie, udając jednak, że jest to nasze własne. Np. obraz Petersburga stworzony w Ustępie przez Mickiewicza został prawdopodobnie w Rosji przyswojony, potem zaś otoczony tabu i zepchnięty do podświadomości. Ale i tak znajdziemy ślady tego obrazu u Nikołaja Gogola, Nikołaja Aleksiejewicza Niekrasowa czy Fiodora Dostojewskiego ${ }^{50}$. Przypadek Puszkina - który w wierszu Jeździec miedziany nawiązuje do Mickiewicza i robi to w sposób raczej spokojny - jest chyba odosobniony. Spokój Puszkina bierze się wszakże stąd, że, dobierając

$47 \quad$ Ibidem, s. 222.

48 Hansen-Löve, op. cit., s. 172 n.

49 Cyt. za: W. Le d n i cki, Aleksander Puszkin. Kraków 1926, s. 99.

50 Zob. cytowaną przez Zi elińs ką (op. cit.) literaturę - W. Le dni cki, Mój puszkinowski Table-Talk. W zb.: Puszkin 1837-1937. Red. M. Zdziechowski. T. 1. Kraków 1939. - S. F is z m a n: wstęp w: A. Puszkin, Jeździec miedziany. Opowieść petersburska. Przeł. J. Tu wi m. Przypisy S. F is z man. Wrocław 1967. BN II 155; Mickiewicz i Puszkin. W zb.: Ze studiów nad literatura rosyjska i polska. Księga poświęcona pamięci profesora Bohdana Galstera. Red. J. Świdziński. Poznań 1999. - B. Gals t e r, Petersburg w pismach Mickiewicza i Gogola. W: Paralele romantyczne. Polsko-rosyjskie powinowactwa literackie. Warszawa 1987. Dotyczące Petersburga związki intertekstualne omawia również Fi e guth (op. cit., s. 230 n.). 
odpowiednio tematykę swoich wierszy (rocznicę Borodino lub pomnik władcy), tak czy owak przemawia $z$ pozycji siły.

Szczególne w obrazie Rosji jest to, iż z wielką łatwością zmienia się stawiane przy nim znaki: przekształcenie pozytywu w negatyw i z powrotem następuje tu nad wyraz płynnie, a przy tym wcale nie potrzeba wymieniać pojedynczych elementów owego obrazu. Czaadajew np., piszac swoją Apologie d'un fou (Apologia obłąkanego), używał takich samych argumentów, za których pomocą krytykował własny kraj, opatrując je tylko znakiem dodatnim. Hansen-Löve omawia tę frapująca procedurę w taki sposób:

Efekt przenicowania polega [...] na tym, że wszystko negatywne, wadliwe i marne nie było widziane jako przeciwieństwo pozytywnego, podniosłego i idealnego, lecz - niejako za sprawą jakiegoś przeskoku - to najbardziej poślednie powinno zmienić się nagle w swoje totalne przeciwieństwo; jak za dotknięciem czarodziejskiej różdżki uczucie niższości zamienia się w wolne od pytań i odpowiedzi poczucie wyższości ${ }^{51}$.

Według Miłosza w XIX wieku w Polsce wykształcił się w stosunku do Rosji „kompleks nie wysłuchanej Kasandry” (M 152). Szkopuł w tym, że polska Kasandra nie mówi Zachodowi nic nowego. Polacy uważają się za ekspertów w sprawie Rosji, powołując się przy tym na stulecia trudnego sąsiedztwa, nierzadko jednak wypowiadają się na temat tego kraju, posługujac się rozpowszechnionymi i gdzie indziej stereotypami. Jak się bowiem zdaje, prawie wszystkie części składowe polskiego stereotypu Rosji można znaleźć na zachodzie Europy ${ }^{52}$. Odkąd Europejczycy od-

$51 \quad$ Hansen - Löve, op. cit., s. 170.

52 Oryginalny u Polaków jest ich stosunek do języka rosyjskiego. U Miłos za (M 156-157) występuje taki oto passus na ten temat: „Głównie, jak się zdaje, przez język, który pociąga Polaków i wyzwala ich słowiańska połowę, zdobywają oni intuicję rosyjskości, w nim jest już wszystko, czego o Rosji można się nauczyć. Jednak co ich pociąga, również im zagraża i pewne ćwiczenie, jakie uprawiałem, kryje w sobie wiele znaczeń. Należało wciągnąć powierze i głębokim basem wymówić: "Wyryta zastupom jama głubokaja", następnie szybko zaszczebiotać tenorkiem: "Wykopana szpadlem jama głęboka". Układ akcentów i samogłosek w pierwszym to ponurość, ciemność i siła, w drugim lekkość, jasność i słabość. Czyli ćwiczenie w autoironii i zarazem ostrzegawcze”. Efekt, o którym pisze Miłosz, jest pewny tylko wtedy, gdy zdanie wypowie się po rosyjsku głębokim basem, a po polsku „tenorkiem”. Przeprowadzenie eksperymentu w odwrotny sposób raczej znacznie zmieniłoby jego wynik. Chodzi więc chyba nie tyle o język, ile o ton, w którym zdanie jest wypowiadane. Walicki (op. cit., s. 150-151) zwrócił uwage na istnienie w Polsce całej tradycji podobnych komparatystycznych ćwiczeń językowych: „myśli tego rodzaju formułowane były przez niektórych wybitnych Polaków na sto lat przed Miłoszem. Fascynacja językiem rosyjskim, jego dźwięcznością, rytmicznością i siłą oraz przeciwstawianie go zlatynizowanemu językowi polskiemu to wątek pojawiający się we wszystkich pismach "narodowego apostaty" Adama Gurowskiego. Co ważniejsze jednak, podobne obserwacje odnajdujemy również w prelekcjach paryskich Mickiewicza. Gdy mówił on o wyższości "tonu" rosyjskiego nad "tonem" polskim, "tonu" Suworowa nad "tonem" Kościuszki, to miał na myśli nie tylko czystą siłę ducha, lecz siłę ducha w ekspresji językowej. Fascynowała go siła rozkazodawcza języka rosyjskiego, możliwość wydobywania z niego "nuty przejmującej strachem", zmuszającej żołnierzy do ślepego posłuszeństwa. Z ubolewaniem konstatował, że język polski nie ma takiej siły: „Mowa polska, rozkwitła w łagodnym cieple chrześcijaństwa, miała inne brzmienie. W tonie Polaków było coś podobnego do tonu monarchii francuskiej wieków średnich, do tonu czasów rycerskich. Ale wieki średnie zostały wstrzymane w swym biegu, a Europa poszła w innym kierunku. [...] Teraz jeszcze sołdaci rosyjscy naśmiewają się z oficerów polskich, że ci jakoby proszą swoich żołnierzy, aby dali ognia, że się kłaniają przed frontem «”. Cytat z A. Mi c- 
kryli Rosję, stała się ona dla nich miejscem projekcji ich własnych lęków i życzeń. Przesady służyły także wzmacnianiu przekonania o wyższości kulturowej. Wszystko to da się wytłumaczyć za pomocą ogólnych reguł tworzenia stereotypów, które znajdziemy np. u Adama Schaffa. Szczególną rzeczą w przypadku Rosji jest jednak, że jej „odkrycie” nastapiło bardzo późno, prawie równocześnie z odkryciem Ameryki, a więc w okresie, gdy Europa zakończyła już swoje wewnętrzne procesy kolonizacyjne. Trwająca stulecia izolacja Rosji spowodowała powstawanie mechanizmów implozyjnych, a także walnie przyczyniła się do „zamrożenia” poglądów na ten kraj.

Moment historyczny, w którym przesąd na temat Rosji zostaje w Europie wywrócony na nice i opatrzony znakiem plus, był dla Polaków szczególny, gdyż w tym samym czasie państwo ich przestało istnieć - i to w dużym stopniu za sprawą Rosji. Po tym jak „nic”, za jakie do tej pory uchodziła Rosja, pozbawiło Polaków państwowej suwerenności i pogrążyło ich w politycznej nicości, stara rywalizacja wybuchła z nieznaną do tej pory moca. Cała europejska opinia publiczna podzieliła się na entuzjastów Rosji i na polonofilów. Ci, którzy oczekiwali od Rosji ratun$\mathrm{ku}$, jak np. francuscy encyklopedyści, uważali rozbiory za sprawiedliwą karę dla Polski. Dla sentymentalisty Jeana-Jacques’a Rousseau, dla którego tylko własne dzieje i sprawdzona w licznych doświadczeniach tradycja była gwarancją pomyślnej przyszłości, Rosja była stracona na zawsze, gdyż w oczach Europy Rosjanie jawili się jako naród ahistoryczny.

Opcja za Rosją wiązała się więc $z$ radykalnym przekreśleniem Polski (i, oczywiście, na odwrót). Rosja albo Polska, ratunek przez Rosję lub śmierć przez nia - tertium non datur. Dewiza ta obowiązywała również po drugiej wojnie światowej. Wtedy linia podziału określana była przez partie polityczne. Lewica w szerokim tego słowa znaczeniu była optymistyczna, a prawica - pesymistyczna w stosunku do roli Rosji w dziejach. Stąd też prawicy przypadł monopol na mówienie prawdy o komunizmie. Dla Miłosza, który sam uważał się za liberała, była to sytuacja niemal tragiczna, bo na Zachodzie mógł on liczyć na zrozumienie tylko u swoich politycznych przeciwników. W okresie rozbiorów ${ }^{53}$, a także po drugiej wojnie światowej Polacy prawie wyłącznie trzymali się negatywnego przesądu. Był to wszak jeden z elementów gwarantujących wewnętrzną integralność i pozwalający skompensować skutki politycznej porażki.

\section{Romantyczne nowości w obrazie Rosji u Mickiewicza}

Mickiewicz stwarza w Drodze do Rosji korespondencję między pustką rosyjskiej przestrzeni a pustką, którą znajduje w twarzach żyjących tam ludzi. Spójrzmy na inny fragment tego utworu:

Oko nie spotka ni miasta, ni góry,

Żadnych pomników ludzi ni natury;

Ziemia tak pusta, tak niezaludniona,

k i ew i c za pochodzi z tomu wykładów Literatura słowiańska. Kurs drugi (w: Dzieła. T. 10 〈przeł. J. Płoszewski〉, s. 417).

53 Wyjątek stanowi tu wczesny okres panowania Aleksandra I. 
Jak gdyby wczora wieczorem stworzona,

[............ . ]

Kraina pusta, biała i otwarta,

Jak zgotowana do pisania karta ${ }^{54}$.

Zofia Stefanowska zwróciła uwagę na fakt, że Mickiewicz (który Rosję znał niewatpliwie lepiej niż chociażby de Custine) szczególnie starannie oczyścił rosyjski pejzaż z całej rosyjskiej tradycji. De Custine zachwycał się np. rosyjskim budownictwem cerkiewnym, które u Mickiewicza po prostu nie istnieje. Obraz rosyjskiej stolicy u Mickiewicza i de Custine’a podsumowuje Stefanowska następująco:

Z konkluzji (de Custine’a) wynika, że, owszem, architektura cerkiewna czerpała ze wschodnich wzorów, ale zostały one przyswojone już tak dawno, że stały się tradycją narodowego budownictwa cerkiewnego. W każdym razie północne mocarstwo ma coś, co może objawić oczom zdumionej Europy.

Zgoła inaczej u Mickiewicza. Jego Petersburg jest biały lub mgliście szary, poeta pozostał zupełnie nieczuły na uroki kolorowego petersburskiego klasycyzmu, niebieskiego i zielonego. I najważniejsze: Petersburg Mickiewicza pozbawiony jest kopuł i dzwonnic cerkiewnych, w Petersburgu Mickiewicza i w ogóle w całym jego opisie Rosji nie ma ani jednej cerkwi. Nie ma w ogóle prawosławia, malowniczego ceremoniału religijnego, ikon, swieczek, nie ma nawet brodatych duchownych ${ }^{55}$.

Chodzi tu o stworzenie wrażenia pustki kulturowej. Również inne motywy wolno rozpatrywać $z$ tego punktu widzenia. Nie bez znaczenia jest fakt, że Mickiewicz w Ustępie wybrał do swoich obserwacji właśnie Petersburg, miasto sztuczne. W mieście tym nie dostrzega on zresztą nic rosyjskiego. Wojsko rosyjskie, ciagnące przez puste równiny, to wyłącznie cudzoziemcy: mongolscy, kałmuccy i litewscy żołnierze oraz francuscy i niemieccy oficerowie. Wszystko inne jest obce i „źle zrobione”. Pustka, którą Mickiewicz odnajduje w spojrzeniu Rosjanina, stanowi więc pendant do pustki rosyjskiego krajobrazu. W obu przypadkach odkrywamy znany już motyw nicości.

Przenoszenie właściwości pejzażu na „Volksseele” (duch narodowy) jego mieszkańców było typowe dla oświecenia. Przede wszystkim Charles de Montesquieu przyczynił się swoimi Listami perskimi do rozpowszechnienia przekonania, że położenie geograficzne kraju, jego klimat, a także inne właściwości geomorfologiczne oddziałują w sposób znaczący na charakter narodowy. Według Montesquieu azjatyckie równiny były odpowiedzialne za panujący tam despotyzm i niewolnictwo, natomiast geofizyczne warunki w Europie miały korzystnie wpłynąć na powstanie idei wolnościowych. Surowy klimat Północy czynił jej mieszkańców silnymi i odważnymi, a łagodny na Południu - zmysłowymi i leniwymi, itd. ${ }^{56}$ Pustka rosyjskiego krajobrazu musi więc znaleźć swój odpowiednik w twarzy Rosjanina. Pustka ta nie świadczy o jakichś własnościach rosyjskiego charakteru, lecz raczej jakby o całkowitym braku cech ludzkich. Czaadajew opisuje Rosjan jako naród znajdujący się na najniższym szczeblu rozwoju społecznego, u Mickiewicza Rosjanie wydają się bardziej podobni do insektów niż do ludzi. Kępiński zestawił miejsca

A. M i c ki e w i c z, Droga do Rosji. W: Dzieła, t. 3, s. 265-266. Podkreśl. M. Z.

Z. S te fa n ow s ka, Mickiewicz wśród „żywiołów obcych”. W zb.: Swojskość i cudzoziemszczyzna $w$ dziejach kultury polskiej. Red. nauk. ... Warszawa 1973, s. 144.

Zob. np. Kępińs ki, op. cit., s. 88. 
u Mickiewicza, w których poeta uprawia podobna jak w Drodze do Rosji „oftalmologię” w stosunku do Rosjan. Wystarczy porównać np. następujacy fragment z Literatury słowiańskiej. Kursu drugiego:

oczy ich podobne są do szklistych kawałków lodu; grozą przejmuje spojrzenie w te oc zy bez dna; odbijają one światło, ale się nie rozgrzewają. Wzrok to żywy, przenikliwy, ale mało wymowny; wzrok nie człowieka ni zwierzęcia, ale raczej owadu. Żeby mieć o tych oczach wyobrażenie, trzeba pod szkłem powiększającym przyglądać się oczom owadów: nieruchomym, błyszczącym, przenikliwym, a zimnym ${ }^{57}$.

Aby właściwie ocenić Rosjan, Mickiewicz zaleca metodę, którą jako romantyk odrzucał. „Miej serce i patrzaj w serce” - nakazuje przecież poeta w Romantyczności, balladzie programowej, negując jednocześnie metody poznania epoki oświecenia, jakich symbolem jest właśnie szkło powiększające. Romantycy chętnie integrowali myśli ludzi oświecenia we własne historiozoficzne wizje ${ }^{58}$. Nie zadowalali się przy tym tylko powierzchnią rzeczy, jak to przytrafiło się przedstawicielom poprzedniej epoki: istota była dla nich na ogół ukryta w głębi, pod powierzchnią wydarzeń (lub też w dalekiej, egzotycznej przestrzeni). Tak jest również w przypadku opisywanych przez Mickiewicza Rosjan: pod spokojną, nic nie mówiącą zewnętrzną warstwą coś się czai i kipi.

Zainteresowanie romantyków głębią (głębia jako temat, symbol, metafora itd.) tłumaczy Maria Janion (nawiązując przy tym do prac Abramsa, Béguina i Bachelarda) ${ }^{59}$ przemianą pojęcia natury, która nastąpiła w romatyzmie. Wyobrażeniu przyrody jako bezdusznego mechanizmu, dominującemu w świadomości Europejczyków od czasów odkryć fizyki newtonowskiej, romantycy - zainspirowani przez Johanna Georga Hamanna i Herdera - przeciwstawili organiczne wyobrażenie świata łączącego zjawiska systemem korespondencji. Ich zainteresowanie kierowało się jednak częściej na sfery podziemne, bogactwa mineralne, kryształy i szlachetne kamienie, wszystko to, co nazywa się naturą nieożywioną, a co dla romantyków było właśnie zdolne w najwyższym stopniu „magazynować” życie. W romantyzmie niemieckim wyobrażenia te łączono głównie $z$ kopalniami w Falun. Zainteresowania głębią doprowadziły do odkrycia światów wewnętrznych, często odczuwanych jako zagrożenie:

Zstapienie w głąb kopalni było zarazem odkryciem podświadomości, erotyka mieszała się z obłędem. Pojawia się tak typowe dla romantyzmu [...] połączenie rewelacji podświadomości $z$ demonizmem. [...]

Odkrycie labiryntów kopalnianych stawało się odkryciem ciemnych labiryntów duszy, korytarzy, lochów i „piwnic jaźni”. [...] Badanie duszy jawiło się jako przygoda czy wyprawa speleologiczna oraz jako „archeologia psychologiczna”, a więc jako czynności schodzenia w ciemną głąb, przenikania do środka, pod powierzchnię ${ }^{60}$.

Poza tą - avant la lettre - freudystyczną interpretacją podświadomości istniało

$57 \quad$ Mi cki e w i c z, Literatura słowiańska. Kurs drugi, s. 87.

58 Zob. np. Kępiń s ki, op. cit., s. 102: „Pielgrzym odczytuje [...] pejzaż ludzki według romantycznej zasady redukowania rzeczywistości do znaków symbolicznych, które - uszeregowane w sekwencje znaczeń - tworzą Księgę przeznaczeń narodu, zapis jego przyszłych losów”.

59 M. J a ni o n, „Kuźnia natury”. W: Prace wybrane. T. 1: Goraczka romantyczna. Red. M. Czermińska. Kraków 2000, s. 302.

$60 \quad$ Ibidem, s. 302-303. 
w romantyzmie również jej wyobrażenie jako „miejsca naszego kontaktu z organizmem uniwersalnym [...]”61, które łączy się raczej z psychoanalizą Carla Gustava Junga.

W polskim romantyzmie, a szczególnie u Mickiewicza, wizje głębi wiążą się głównie ze skłonnością do tematów i metafor tworzących następujące ciągi: „ziarno - grób - ciemność - wiosenne zmartwychwstanie” oraz „wulkan - ogień wewnętrzny - ogień podziemny - wybuch wulkanu"62. Owe ciągi obrazów łączą się przede wszystkim $\mathrm{z}$ romantycznymi ideami rewolucyjnymi:

Romantyzm pojmuje odnowę i rewolucję jako erupcję podziemnego „wewnętrznego ognia”, jako wybuch wulkanu. Ale zarazem w podziemiu, w twórczych ciemnościach kiełkuje ziarno - nieśmiertelne, jak nieśmiertelny jest rytm natury. [...] Bezruch ziarna jest pozorny: w nim wszak rozwija się siła życia, życia najbardziej intensywnego i „wewnętrznego” zarazem. Wulkan i ziarno po równi dojrzewają ${ }^{63}$.

U Miłosza znajdujemy bardzo wyraźną inklinację do środków artystycznych, które - jak to sformułował Ryszard Nycz - „poprzez oczyszczająca redukcję pozwalają spojrzeć "w głąb", a jednocześnie "na istotę rzeczy""64. Miłosz wykorzystuje romantyczną głębię w postaci wykreowanej przez Mickiewicza, funkcjonalizując ją nawet $\mathrm{w}$ podobny sposób.

Mickiewicz przywołuje opisywane ciągi metaforyczne nie tylko w Ustępie, lecz również w trzeciej części Dziadów. W scenie VII dramatu młody spiskowiec Wysocki wypowiada o narodzie polskim następujący sąd:

[...] Nasz naród jak lawa,

$Z$ wierzchu zimna i twarda, sucha i plugawa,

Lecz wewnętrznego ognia sto lat nie wyziębi;

Plwajmy na tę skorupę i zstąpmy do głębi! ${ }^{65}$

Również tutaj „forma zewnętrzna” narodu przedstawiona jest w negatywnych obrazach. Pod tą powierzchnią płonie wszakże czysty ogień, a ten ma znaczenie niewątpliwie pozytywne. W odniesieniu do imagotypu Rosjan w Ustępie Mickiewicz używa także metafory wulkanu. Kiedy jednak próbuje wyrazić swoje na wskroś ambiwalentne nastawienie do Rosji, sięga po metaforę ze skarbca topiki antycznej66. Ambiwalencję tę wyrażają wersy kończące przywołaną wcześniej za Miłoszem strofę z Drogi do Rosji:

$61 \quad$ Ibidem, s. 281.

62 Ibidem, s. 295.

63 Ibidem, s. 313.

64 R. Ny c z, Miłosz: bio-grafia idei. W: Sylwy współczesne, s. 50-51. Cz. Miłos z opisuje metodę Traktatu moralnego (w: Wiersze. Kraków 2002, s. 86. Dzieła zebrane. T. 2) (1947) w następujący, bardzo przypominający Mickiewicza sposób:

Podobnie w nasze dni zamglone

Stylem zasnute jak kokonem,

Sięgaj i przędzę bierz za przędzą,

Aż kruche nitki się rozkręca

I na dnie $z$ wolna się ukaże

Poczwarka nietykalna zdarzeń. 
Ale gdy słońce wolności zaświeci,

Jakiż z powłoki tej owad wyleci?

Czy motyl jasny wzniesie się nad ziemię,

Czy ćma wypadnie, brudne nocy plemię? ${ }^{67}$

Tym razem chodzi więc o przeciwstawienie odpychającej formy zewnętrznej głęboko ambiwalentnemu wnętrzu. To wnętrze w przyszłości może objawić się na powierzchni jako „motyl jasny” lub jako „brudna” „ćma”. Jako rewolucjonista romantyczny nie posuwa się Mickiewicz tak daleko, by w swym utworze ogłaszać, że rewolucja, która innym narodom ma przynieść wolność, w przypadku Rosji z pewnością zawiedzie. Jego wypowiedź pozostaje ambiwalentna, nie zaś całkowicie negatywna. Niemniej jednak owa „dusza-gasiennica” jest w cytowanym przez Miłosza fragmencie przede wszystkim podświadomościa nie rozjaśniona światłem ludzkiej kultury, „piwnica jaźni”, a więc jednym z głównych źródeł lęku romantycznego.

Miłosz cytując Mickiewicza pomija te dwa zamykające cytat wersy. Ostatni wers stanowi w ten sposób pytanie retoryczne. Albowiem dla Miłosza skutki rewolucji w Europie Środkowej i Wschodniej sa już wiadome. Owa nic nie mówiąca „powierzchnia” Rosjan, której przeciwstawione zostaje wnętrze równie obce i wzbudzające lęk, okazuje się dla Miłosza i tremendum, i fascinosum. Rosja i Rosjanie dla obu wielkich poetów stanowią ucieleśnienie tego, co Freud nazwał das Unheimliche $^{68}$.

\section{Ujawnienie urazu}

W pierwszej fazie literackiej psychoanalizy podstawową strukturę komunikacyjną w eseju Rosja stanowił trójkąt utworzony przez eseistyczny podmiot refleksji oraz dwóch bohaterów zbiorowych, Rosjan i Polaków. Posługując się mową pozornie zależna Miłosz nadał swoim bohaterom stopień samodzielności typowy raczej dla powieści niż dla eseju. $Z$ tego powodu auktorialny podmiot w zaprezentowanej tu części eseju może zostać nazwany narratorem. Podstawowe natomiast dla eseju rozszczepienie eseistycznego ,ja” na podmiot refleksji i opisywany z dystansu czasowego jej przedmiot pojawia się w Rosji dopiero na drugim etapie analizy (czy też w wydzielonej nieco sztucznie przeze mnie drugiej części utworu). „Ja” jako podmiot refleksji w eseju rzadko tylko zdradza swoje emocje bezpośrednio; instancją przeżywającą i odczuwająca jest to drugie ,ja”, umieszczone w przeszłości i występujące jako obiekt refleksji. W Rosji ukazuje się ono najpierw jako "ja” pokoleniowe między dwiema światowymi wojnami. We fragmencie tym podmiot definiuje własne odczucia w stosunku do Niemców, przeciwstawiając je później swojej percepcji Rosjan. Niemców spostrzega on jako „Marsjan niewyobrażalnych od środka” (M 156).

67 Mickiewic z, Droga do Rosji, s. 268.

68 Zob. przypis 8. Jak już wspomniano, u Mickiewicza i Miłosza mamy do czynienia z wyobrażeniem Rosjan jako organizmów wprawdzie żywych, lecz znajdujących się na etapie rozwoju ewolucyjnego o wiele niższym niż człowiek. Rosjanie u Mickiewicza przypominają owady, należą więc do świata przyrody ożywionej, ale bezdusznej. 
Miłosz sięga tutaj do numinalnego imago „obcego”, opisywanego często przez etnologów, charakterystycznego dla ludów kolonizowanych ${ }^{69}$. Według tej definicji obcy stoi zawsze w sensie sakralnym ponad podmiotem owego wyobrażenia (jako rodzaj bóstwa - Niemcy u Miłosza pochodzą przecież „Z góry”, z Marsa), albo też p o niż ej niego, tzn. należy do królestwa ciemności. W tym samym akapicie, jakby na tym samym oddechu, podmiot eseju stwierdza, że Rosja w przeciwieństwie do Niemiec „była względnie, tylko względnie zresztą, konkretna, jako pamiętany z dzieciństwa chaos i bezmiar [...]" (M 156). Zdanie to można, oczywiście, odnieść do wspomnień Miłosza $z$ dzieciństwa, kiedy podczas rewolucji październikowej podróżował on $\mathrm{z}$ rodzicami po Rosji ${ }^{70}$, wolno jednak upatrywać w nim również obrazu dziecięcej psyche, gdy osobowość pozbawiona jest jeszcze wyraźnych granic, drzemiąc w głębinach podświadomości. Wyobrażenie - że polska niedojrzałość kulturowa czyni ją podatną na wpływy Rosji, która $z$ kolei jest jakąś polską podświadomością - występuje zresztą u Miłosza częściej. Lęk przed Rosją okazuje się wtedy lękiem przed własną podświadomością, zdającą się zagrażać chwiejnemu ego. W okresie międzywojennym podmiot dystansuje się jednak od rosyjskiej „obsesji”, typowej dla starszych od niego Polaków:

Dla mojego pokolenia tamte, minione, powikłania wydawały się mroczne i odległe. Wychowaliśmy się w normalnym państwie, a jego blaski i nędze były normalną sprawą, bo decyzje najoczywiściej zapadały w Warszawie, nie gdzie indziej. Męczeństwo, spiski, zsyłki na Sybir figurowały w podręcznikach i budziły tylko współczucie, a nawet rozsądek doradzał nam odnosić się z kpiną do całego romantycznego patosu przeszłości. Rosja istniała w mojej wyobraźni, ale w stanie jakby p r zy ć m i o n y m. Ostatecznie spór został jako tako zlikwidowany i dzieliły nas graniczne słupy. I na straży stało tabu zabraniające zastanawiać się nad możliwością wprowadzenia u nas ich systemu. Marksizm, rewolucja, owszem, ale nie ich. Niech u siebie robią, co chcą, nas to nie dotyczy. Wolno uznać taki pogląd za głupi. Jednak pod tym względem byłem okazem typowym, ten próg zakazu był rzeczywisty i jakikolwiek polityk, jeżeli nie bierze go pod uwage, popełnia błąd. [M 155-156]

W tym stosunkowo krótkim okresie niezawisłości polskiego państwa przesąd miał charakter latentny, szczególnie przez młodszą generację zepchnięty został do osobistej i kolektywnej podświadomości. Na powierzchni widoczny był tylko nieuzasadniony sprzeciw wobec realizowanego „tam” systemu politycznego.

Jednak przeżycie traumatyczne podmiotu eseju wydobywa obsesję znowu na

Ju. Łotman i B. Uspienski („Odszczepieniec” i „odszczepieństwo” jako pozycje społeczno-psychologiczne $w$ kulturze rosyjskiej - na materiale z epoki przedpiotrowej 〈„Swoje” $i$,obce” $w$ historii kultury rosyjskiej〉. W: Semiotyka dziejów Rosji. Wybór, przeł. B. Żył k o. Łódź 1993) wyróżniają poza „horyzontalnym” pojęciem obcego (jako wroga lub migranta, żyjącego na "naszym” terytorium, ale należącego właściwie do innego, zewnętrznego świata) również pojęcie „wertykalne”. Ta druga kategoria zawiera tzw. naszych obcych: „naszym obcym" okazuje się szaman, czarownik, prorok, należący jednocześnie do "naszego" - ziemskiego, i "obcego", pozaziemskiego świata. W pierwszym wypadku "obcy" jest przedmiotem wrogości lub ochrony, w drugim - strachu i szacunku. Stwarza to możliwość psychologicznej zamiany w stosunku do dwóch danych różnorodnych grup: we wszelkim obcym można widzieć czarownika i odnosić się do niego z trwożnym szacunkiem, a do czarownika i szamana, nawet przy ich oczywistej "swojskości" - z podejrzliwością, jako do agentów wrogich sąsiadów" (ibidem, s. 62). Miłosz operuje więc pojęciem obcego wertykalnym (choć nie ściśle sakralnym) zarówno w stosunku do Niemców, jak i do Rosjan.

70 Cz. Miłosz opisuje tę fazę swojego dzieciństwa w rozdziale Rodzinnej Europy pt. Dziesięć dni, które wstrzasnęty światem. 
zewnątrz. W styczniu 1945 Miłosz staje się świadkiem pojmania niemieckiego żołnierza przez żołnierzy radzieckich:

Może powinienem był go nienawidzić, przede wszystkim za głupotę, która mnożąc się przez głupotę milionów takich jak on, podarowała władzę Hitlerowi, a $z$ niego zrobiła ślepe narzędzie mordu. Ale nie znalazłem w sobie nienawiści. [...] Oni też go nie nienawidzili. Ponieważ bał się, jak złapane w klatkę zwierzę, nieznanego, jeden $z$ nich wstał i dał mu papierosa, ten ruch ręki oznaczał pojednanie. Inny podszedł i poklepał go po plecach. Potem zbliżył się do niego podoficer i powoli, dobitnie, wygłosił do niego długie przemówienie. Było to bezużyteczne, bo Niemiec nic nie rozumiał, ale przylepiał oczy do ust mówiącego; pies, który stara się odgadnąć treść słów swego pana. I jednak z przyjaznego tonu wywnioskował, że nie chcą się mścić, nie chcą wyrządzać mu krzywdy. Niech się nie boi - powtarzał z naciskiem podoficer. Nic złego mu się nie stanie, wojna dla niego już skończona, nie jest już wrogiem, ale zwykłym człowiekiem, będzie pracować dla pokoju i zaraz zostanie odprowadzony na tyły. Litość, a nawet serdeczność w głosie, łagodna powaga autorytetu uspokajały jeńca i nieśmiało uśmiechnął się; wdzięczność. [M 159-160]

Następująca po tej scenie egzekucja Niemca jest przerażająca i szokująca również dlatego, że stanowi przeciwieństwo oczekiwań czytelnika:

Kiedy jeden z żołnierzy zebrał się sennie ze swojej ławy, choć nie padł żaden rozkaz, i wziął go z izby, powrócili w poprzednią apatię, odpoczynek ludzi fizycznie strudzonych. Po upływie paru minut konwojent wrócił wlokąc za sobą biały kożuch, rzucił go obok swego worka, siadł i skręcał papierosa. We wciąganiu dymu, w pluciu na podłogę zawarta była ich melancholijna refleksja o kruchości życia ludzkiego [...]. [M 160]

Miłosz przestrzega przed ocenianiem tego wydarzenia poza jego historycznym kontekstem i przypomina o głodowej śmierci tysięcy radzieckich żołnierzy w nazistowskiej niewoli. Także żołnierze alianccy „niekiedy umieli dyskretnie sprzątać Niemców" (M 160). Jego zdaniem, nie należy również opisanego epizodu mierzyć według kryteriów europejskiej kultury, gdyż etapem przygotowawczym zbrodni podczas drugiej wojny światowej była perwersja owej kultury:

ofiary wyłączano najpierw we własnej wyobraźni poza nawias człowieczeństwa, przekształcano we wstrętne kukły i następnie mszczono się na tych przedmiotach; cały ten proces psychiczny był na przykład planowo popierany przez nazich, obrócony przeciwko Żydom i Polakom. [M 160-161]

Czynów żołnierzy radzieckich nie da się, zdaniem Miłosza, wytłumaczyć w taki sposób, gdyż nie widać u nich nienawiści. Ich ludzkość nie jest również udawana:

Odegraną przez nich komedię humanitarną ktoś mógłby nazwać podstępem, gdyby nie odpowiadała najwyraźniej ich wewnętrznej potrzebie. Ze szczerym przeżyciem szło zresztą w parze przekonanie, że taką operację należy przeprowadzać możliwie najłagodniej i najciszej. [...]

[...] oni tutaj nie zabili go z nienawiści, ale z szacunku dla k o n i e c z n o ś c i. [M 161; podkreśl. M. Z.]

Dla Miłosza zachowanie się rosyjskich żołnierzy stanowi następstwo długiego rozwoju historycznego:

Łańcuch przyczyn i skutków historycznych urabiających jakąś zbiorowość jest długi i jednostki poddające sie jej nakazom nie zdają sobie sprawy z tego, co je naznaczyło takim, a nie innym znamieniem. Ostatnie ogniwa łańcucha, to jest ustrój, nie wydawały mi się [...] czymś rozstrzygającym, bo ustrój nie wyrasta przecie w próżni i choć jako dzieło dokonane mógł już stanowić towar eksportowy, określiła jego cechy tamtejsza, ich rodzima gleba. [M 161] 
Tłumacząc to wydarzenie, Miłosz sięga najpierw znowu do wyobrażeń zbiorowych: ,i nie gardziłem polskim stereotypem, według którego Rosjanin, zarzynając kogoś, potrafi nad swoją ofiara płakać rzewnymi łzami” (M 161). Wzorcowe sformułowanie tego „stereotypu” należy również do Mickiewicza. W kursie trzecim swoich wykładów pt. Literatura słowiańska opisuje on dzieła antyczne uważane za wizerunki Słowian, m.in. posag znany jako Scyta lub Szlifierz, znajdujący się do dziś w galerii Uffizi we Florencji:

Rzeźba ta przedstawia człowieka, który przykucnąwszy ostrzy szeroki nóż. Nie pamiętam, czy to Winckelmann, czy Visconti pierwszy zauważyl, iż ów barbarzyńca wygląda, jakby się gotował do męczenia jakiejś ofiary, i że rzeźba należała prawdopodobnie do grupy Marsjasza. Jak wiadomo, Marsjasz został skazany przez Apollina na odarcie żywcem ze skóry, i ten człowiek to niewolnik mający niewątpliwie wykonać straszliwy wyrok. [...] Jesteśmy przekonani, że typ Szlifierza jest słowiański [...]; kąt licowy odmierzony cyrklem wykazuje liczbę stopni, według której odróżniamy czaszkę Słowianina od czaszek innych plemion barbarzyńskich. [...]

Na pierwszy rzut oka w postawie Szlifierza, w jego twarzy i spojrzeniu nie masz nic groźnego ani dzikiego, a jednak odczuwamy zaraz, że nie jest to jakiś rzemieślnik, że ostrzy on nóż na coś zgoła innego niż na zwyczajną robotę. [...] Głowa jego piękna, lecz czoło nieco wklęsłe, wyłysiałe i pomarszczone. Ustawienie głowy, łysina, chude i zapadłe policzki wskazują człowieka, który długo musiał cierpieć i milczeć; [...]. Tak wygląda ów kat słowiański, zatrzymujący z uczuciem męki błędne spojrzenie na swej ofierze, wzdrygający się na myśl, że musi ją katować, i cichym uśmiechem zdradzający, że nie może się oprzeć konieczności; poddaje się jej wszelako, smutny, przerażony, lecz gotów do posłuszeństwa.

Pośród tysięcy starożytnych posagów nie znajdziesz drugiego, co by miał takie piętno okrutnej dobroduszności, jakiegoś posępnego i złowróżbnego poddania się; wyraz uczucia, na jakie w językach zachodnich nie ma nazwy, a jakiego doznaje często Rosjanin wymawiając słowo: słuszaju-s ${ }^{71}$.

Jak się zdaje, mamy tu do czynienia z przesądem in statu nascendi. Jest rzeczą bardzo prawdopodobną, że antyczna rzeźba z grupy Marsjasza, którą ciagle jeszcze podziwiać można w galerii Uffizi, skojarzyła się Mickiewiczowi z czasem spędzonym w Rosji i z konkretnymi tam przeżyciami. Analogiczne wyobrażenia o stosunku Rosjan do władzy państwowej również dzisiaj kształtują stereotyp na temat Rosji. $Z$ drugiej strony, paralela, którą Mickiewicz konstruuje między legendarnym czasem Słowian (Scytowie są mitycznymi przodkami Rosjan, podobnie jak Sarmaci - Polaków), sprawia, że w rosyjskim stosunku do władzy zaczynamy dostrzegać coś fatalnego i nieuniknionego, ustanowionego niejako antropologicznie.

Miłosz natomiast przyczyn historycznych szuka w postępowaniu żołnierzy i wyjaśnia je dualistycznym wzorem myślenia, panującym w kulturze rosyjskiej. Trzeba jednocześnie stwierdzić, że w ten sposób denuncjuje także samego siebie, ponieważ tak w twórczości Miłosza, jak i w jego życiu osobistym oraz publicznym wpływ gnozy zaznaczył się wyraźnie ${ }^{72}$. Również w eseju Rosja poeta wskazuje palcem na siebie. Przyczyn ugruntowania się dualistycznego modelu kultury Miłosz szuka w dość odległej przeszłości. Zwraca uwagę przede wszystkim na rozprzestrzenianie się idei gnostyckich w średniowiecznej Rosji i na ich powtórne pojawienie się w literaturze rosyjskiej w drugiej połowie XIX wieku (głównie u Dostojewskiego

71 A. Mickiewicz, Literatura słowiańska. Kurs trzeci i czwarty. W: Dzieła, t. 11 (przeł. J. Płoszewski), s. 241-243.

72 Zob. M. Zemła, Tygrys - gnoza polityczna. „Postscriptum Polonistyczne” 2011, nr 2. Tam również obszerna literatura przedmiotu. 
i Władimira Sołowiowa). Dla Miłosza centralne znaczenie ma gnostycka eschatologia, czyli doktryna apokatastazy, odnowy stworzenia na końcu czasu:

$Z$ bezlitosności przyrody i bezlitosności społecznego porządku sekciarze czerpali pewność, że świat jest w niepodzielnym władaniu Szatana. Jedynie Królestwo Boże miało obalić jego prawo tożsame z prawem Stworzenia. Dlatego rosyjscy pisarze mistyczni sądzili, że w dzień, kiedy spełni się Królestwo Boże, zbawiony będzie nie tylko człowiek, ale również mucha i mrówka. [M 161-162]

Porównanie systemu kulturowego Rosji $z$ dualistycznym modelem gnozy nie było w okresie powstania Rodzinnej Europy pomysłem nowym. Idea ta pojawia się m.in. w dziełach Nikołaja Bierdiajewa ${ }^{73}$. Bierdiajew wywarł głęboki wpływ na polskiego historyka idei i teoretyka cywilizacji Bogumiła Jasinowskiego ${ }^{74}$. Argumenty Miłosza pochodza prawdopodobnie od tego ostatniego uczonego. W czasie pisania Rodzinnej Europy temat ten nie był jednak szczególnie aktualny: brakowało przede wszystkim podstaw metodologicznych, które pozwoliłyby oglądać kulturę rosyjska sub specie gnosis ${ }^{75}$. Nowe możliwości stworzyła w tej dziedzinie metoda badań strukturalnych. Krótko przed ukazaniem się Rodzinnej Europy Claude Lévi-Strauss zwrócił uwagę na decydujące znaczenie, jakie dla dynamizacji procesów cywilizacyjnych ma przejście od systemów binarnych do ternarnych ${ }^{76}$. Teoria Lévi-Straussa została przyjęta z zainteresowaniem przez uczonych tartusko-moskiewskiej szkoły semiotyki i spożytkowana w pracach na temat kultury rosyjskiej. Głównie pisma Łotmana i Uspienskiego, ukazujące się od drugiej połowy lat siedemdziesiątych ubiegłego wieku, przyczyniły się w sposób znaczący do utrwalenia poglądu o przeważającym wpływie systemów dualnych na kulturę Rosji ${ }^{77}$. Spróbujmy teraz przyjrzeć się argumentom Miłosza w świetle strukturalno-semiotycznej teorii.

\section{Apokatastaza i pojęcie historii w kulturze rosyjskiej}

Również historycy potwierdzają znaczny wpływ gnozy na średniowieczną Rosję - i to przede wszystkim w obrębie ortodoksji. W Rosji sekta bogomiłów nie funkcjonowała bowiem bezpośrednio, jej działanie ograniczało się do rozpowszechnianych pism apokryficznych. Nieobecność samej sekty w paradoksalny sposób zwiększyła jej znaczenie, ponieważ wskutek tego oddziaływanie jej nie było łatwo uchwytne dla

73 Najważniejsze dzieło N. Bi erdiajewa na ten temat, Rosyjska idea (oryg.: Russkaja idieja. Osnownyje problemy russkoj mysli XIX wieka i naczała XX wieka), wydane zostało w Paryżu dopiero w 1946 roku.

74 B. J a s i now s ki, Wschodnie chrześcijaństwo a Rosja. Wstęp M. Kor n a t. Przypisy S. Gó r ka. Kraków 2002 (wyd. 1: 1933).

75 Jasinowski uprawia po części psychologię narodów, dziedzinę, która po drugiej wojnie światowej została przez świat naukowy odrzucona.

76 C. Lévi-Stra us s, Czy istnieją organizacje dualistyczne? W: Antropologia strukturalna. Przeł. K. Pomian. Warszawa 2000 (wyd. 1: Paris 1958).

77 Ju. Łotman, B. Us pien ski, Rola modeli dualnych w dynamice kultury rosyjskiej (do końca XVIII wieku). W zb.: Semiotyka dziejów Rosji. Oryginał rosyjski ukazał się w 1977 roku. 
ortodoksyjnej hierarchii. Myśl gnostycka znalazła w Rosji doskonałe podłoże, gdyż w kulturze nieoficjalnej ciagle żywa była słowiańska tradycja pogańska i jej mitologia, a dualizm gnostycki bliski jest archaicznej mitologiii ${ }^{78}$.

Aby powstrzymać zalew pism heretyckich, Kościół prawosławny od XIV wieku (a, być może, już wcześniej) publikował Indices. Jednak także w dziełach kanonicznych, jak np. w bardzo rozpowszechnionej Palei, wolno dopatrywać się wpływów gnozy. W ten sposób jej oddziaływanie utrwaliło się również oficjalnie.

Doktryna apokatastazy (lat. restitutio), tj. odtworzenia Boskiego porządku we wszechświecie po upływie eonu, występuje u stoików i w Dziejach Apostolskich ${ }^{79}$. Wersja apokatastazy - opracowana przez Orygenesa - została jednak odrzucona jako herezja tak przez Kościół zachodni, jak i wschodni. W gnostyckiej nauce o Zbawieniu apokatastaza odgrywa natomiast istotną rolę. Fakt ten może dziwić, gdyż gnostycy głosili równocześnie, że apokatastaza nastąpić ma po apokalipsie i Sądzie Ostatecznym. W Rosji zainteresowanie tą doktryną wzrasta w drugiej połowie XIX wieku, zajmuje ona np. Dostojewskiego i Sołowiowa.

Według Miłosza model zaświatów oparty na apokatastazie został w kulturze rosyjskiej zsekularyzowany. Miało to, jego zdaniem, istotne konsekwencje dla ukształtowania się rosyjskiej mentalności:

To nadludzkie niemal współczucie przecinało jednak w praktyce więź pomiędzy intencją i czynem. Bo skoro, zanim przyjdzie Chrystus, jesteśmy całkowicie poddani haniebnemu prawu, bunt naszego serca jest bezsilny. [...]

Kiedy przetnie się więź między intencją i czynem, szlachetne słowa, przyjacielskie uściski, łzy szczerych wyznań i cała urocza wylewność rosyjska są wycieczką w krainę wolną od przymusu ziemskich praw, krainę, gdzie człowiek człowiekowi jest bratem. Głębia przeżyć autentyczna, przyzwolenie dane sobie pełne - choć równocześnie jakaś warstwa w nas nie łudzi się, że to tylko przyzwolenie. Nie będzie niekonsekwencją, jeżeli zaraz potem zadenuncjuje się albo zabije przyjaciela, ponieważ nie my jesteśmy winni, ale zły świat. [...] Takie jednak zrzucanie $z$ siebie odpowiedzialności łatwo przekształca się $w$ nałóg i wtedy próg, za którym zaczyna się rzekoma konieczność, jest bardzo niski. Popełnia się zło bez zapału, ale nie robiąc nic, żeby go uniknąć. Przy tym podejrzewa się, że każdy akt wolny maskuje tylko uległość wobec materialnego przymusu. [M 162-163]

Również Łotman i Uspienski wskazują na model zaświatów wschodniego chrześcijaństwa jako jego decydująca differentia specifica. W przeciwieństwie do rzymskiego katolicyzmu - argumentuja - w którym przyjęto model trzyczęściowy (niebo, piekło i czyściec), we wschodniej ortodoksji zdecydowanie odrzucono ideę purgatorium. Zdaniem obu autorów, miało to znaczące skutki dla utrwalonego modelu kultury rosyjskiej, modele zaświatów $z$ reguły przenoszone są bowiem na świat

Zob. A. A. H a n s e n - Lö ve, Allgemeine Häretik, russische Sekten und ihre Literarisierung in der Moderne. „Wiener Slawistischer Almanach” t. 41 (1996): Orthodoxien und Häresien in den slavischen Literaturen, s. 172 n., $190 \mathrm{n}$.

79 Zob. Dz 3, 19-21: „Pokutujcie więc i nawróćcie się, aby grzechy wasze zostały zgładzone, aby nadeszły od Pana dni ochłody, aby też posłał wam zapowiedzianego Mesjasza, Jezusa, którego niebo musi zatrzymać aż do czasu odnowienia wszystkich rzeczy, co od wieków przepowiedział Bóg przez usta swoich świętych proroków” (cyt. z: Pismo Święte Starego i Nowego Testamentu $w$ przekładzie z języków oryginalnych. Oprac. Zespół Biblistów Polskich [...]. Biblia Tysiąclecia. Wyd. 5, na nowo oprac. i popr. Poznań 2002. Podkreśl. M. Z.). 


\section{doczesny i jego organizację $e^{80}$. Tak więc na obszarze, na którym rozprzestrzenił się} rzymski katolicyzm, możliwe są trzy rodzaje zachowania:

bezwzględnie grzeszne, bezwzględnie święte i pośrednie, jakby neutralne, dopuszczające zbawienie pozagrobowe po pewnym oczyszczającym doświadczeniu. Tym samym w realnym życiu zachodniego średniowiecza okazuje się możliwa szeroka strefa neutralnego zachowania, neutralnych instytucji społecznych, które nie są ani „święte”, ani „grzeszne”, ani „państwowe” ani „antypaństwowe”, ani dobre, ani złe. Ta neutralna sfera staje się strukturalną rezerwą, z której rozwija się system jutra ${ }^{81}$.

\section{W systemie rosyjskiej kultury średniowiecznej „przejściowych neutralnych stref} nie przewidywano".

Zgodnie z tym i w życiu ziemskim zachowanie mogło być albo grzeszne, albo święte. Rozprzestrzeniało się to także na pojęcia pozakościelne; na przykład władza świecka mogła być traktowana jako boska lub diabelska, ale nigdy jako neutralna w stosunku do tych pojęćc

$80 \quad$ Ło t m a n, U s p i e n s ki, Rola modeli dualnych $w$ dynamice kultury rosyjskiej (do końca XVIII wieku). Pogląd ten pokrywa się całkowicie z ustaleniami J. Le Goffa, referowanymi w nieco później opublikowanej książce Narodziny czyśćca (Przeł. K. Ko cjan. Posł. Z. Mi k ołej ko. Warszawa 1997 〈wyd. 1: Paris 1981〉, s. 10-11): „Organizacja rozmaitych przestrzeni - geograficznej, ekonomicznej, politycznej, ideologicznej itd. - w których funkcjonują społeczeństwa, jest bardzo ważnym aspektem ich historii. Organizowanie przestrzeni swych zaświatów było dla społeczeństwa chrześcijańskiego zabiegiem o dużym znaczeniu. Kiedy czeka się na zmartwychwstanie zmarłych, geografia tamtego świata nie jest rzeczą drugorzędną. Można się też spodziewać, że istnieją związki między sposobem, w jaki dane społeczeństwo organizuje swą przestrzeń na ziemi i swą przestrzeń w zaświatach. Albowiem obie one powiązane są wskutek relacji, które jednoczą społeczeństwo zmarłych i społeczeństwo żywych. Między 1150 i 1300 rokiem chrześcijaństwo oddaje się właśnie dziełu wielkiej reorganizacji kartograficznej na ziemi i w zaświatach. Dla społeczeństwa chrześcijańskiego, takiego jak społeczeństwo średniowiecznego Zachodu, wszystko toczy się w tym samym - lub prawie tym samym - czasie na ziemi i w niebie, na tym i tamtym świecie”. Dysputa między Wschodem a Zachodem na temat struktury zaświatów odbywała się na tle prób zjednoczeniowych, podejmowanych od końca XII wieku. Pertraktacje z tym związane doprowadziły do doraźnego sformułowania doktryny czyśćca (dogmatem stało się purgatorium dopiero w okresie Tridentinum). Kościół wschodni ostatecznie odrzucił ideę czyśćca na Soborze Lyońskim II (1274). Zdaniem Le Goffa, goszczący na nim kler wschodni uznał zachodnią koncepcje purgatorium za główną przeszkodę dla ponownego zjednoczenia. Skomplikowane polityczne i teologiczne tło tych procesów prezentuje cytowana książka Le Goffa. Znaczący wydaje się fakt, że przedstawiciele Kościoła wschodniego odrzucili idee „trzeciego miejsca” w zaświatach, gdyż zbytnio przywodziła ona na myśl apokatastazę: „To przecie Orygenes wraz ze swymi poplecznikami nauczał, iż nastapi kiedyś kres piekła i że nawet diabły po jakimś czasie uzyskają przebaczenie i uwolnienie od kary wiecznej” (Le G off, ibidem, s. 284). Według autora nie można z całą pewnością powiedzieć, czy to idea czyśćca przygotowała przemiany społeczeństwa średniowiecznego, czy też odwrotnie, istniejąca już świadomość stopnia pośredniego (w logice, matematyce i strukturze społecznej - trzeciego stanu) „wywołała” również doktrynę czyśćca. Le Goff zdaje się skłaniać ku tej drugiej teorii i powołuje się na przedstawiciela Kościoła zachodniego, który stwierdza, że to właśnie wierni nie będą się dłużej zadowalać binarną strukturą zaświatów.

81 Ło t m a n, U s p i e n s ki, Rola modeli dualnych $w$ dynamice kultury rosyjskiej (do końca XVIII wieku), s. 18-19.

82 Ibidem, s. 19. Najbardziej uznane w ortodoksji wschodniej modele zaświatów opisuje wybitny teolog XX wieku, S. Bułgakow (Prawosławie. Zarys nauki Kościoła prawosławnego. Przeł. H. Pa procki. Białystok-Warszawa 1992, s. 198-199. Podkreśl. M. Z. 〈wyd. 1, niepełne: Paris 1932; wyd. 1, pełne: Paris 1964)), w następujący sposób: „Kościół prawosławny rozróżnia możliwość trzech stanów w życiu pozagrobowym: rajskiej szczęśliwości i dwojakich mąk piekielnych - z możliwością uwolnienia od nich przez modlitwy Kościoła i wewnętrzny proces zachodzący w duszy oraz 
Można więc uważać, że Miłosz w swoim eseju zapoczątkował jakiś nowy etap w dyskusji o Rosji, który prawie dwa dziesiątki lat później rozwinięty został przez tartusko-moskiewskich semiotyków (ci ostatni raczej tego eseju nie znali). Semiotycy nie włączyli do swych rozważań doktryny apokatastazy. Tymczasem znaczenie tej doktryny w systemie rosyjskiej kultury wydaje się niebagatelne. Zainteresowanie nią wzrosło w ciągu wieku XX również w kręgach oficjalnej teologii rosyjskiej, powołującej się przy tym na definicję św. Grzegorza z Nyssy. Świadectwem tego jest choćby następujacy passus z Siergieja Bułgakowa:

W eschatologii były [...] dwa ukierunkowania: jedno - rygorystyczne, głoszące wieczność cierpień, oraz drugie - św. Augustyn nazywał ironicznie zwolenników tego poglądu „miłosiernikami” (misericordes) - odrzucające wieczność cierpień i obecność zła w stworzeniu oraz wyznające ostateczne zwycięstwo Królestwa Bożego, gdy Bóg będzie „wszystkim we wszystkich”. Naukę o apokatastazie reprezentował nie tylko wzbudzający wątpliwości co do ortodoksyjności swych poglądów Orygenes, ale także św. Grzegorz z Nyssy, czczony przez Kościół jako Ojciec Kościoła. Uważano, że nauka Orygenesa o apokatastazie została potępiona przez V Sobór Powszechny, jednakże współczesne badania historyczne odrzuciły ten pogląd, natomiast nauka Grzegorza z Nyssy, bardziej stanowcza i logiczna, nigdy nie była potępiona, przez co można ją traktować przynajmniej jako autorytatywny pogląd teologiczny (theologoumen) w Kościele ${ }^{83}$.

Nauka św. Grzegorza z Nyssy o apokatastazie jest uznawana również w Kościele katolickim, jednak tylko w sensie nauki dodatkowej. Gdyż sama Paruzja, ponowne przyjście Chrystusa, odgrywa tu rolę drugorzędną: Zbawienie dokonało się już przez pierwsze Jego przyjście. Krytycznie nastawiony do katolicyzmu Bułgakow wyjaśnia ten fakt w następujący sposób:

W Kościele zachodnim zatryumfowała nauka św. Augustyna, według którego civitas Dei oznacza Kościół katolicki, do którego odnosi się również proroctwo Apokalipsy głoszące tysiącletnie królestwo (Ap 20, 1-6), a także proroctwa starotestamentowe głoszące królestwo mesjańskie. [...] zwyciężyła interpretacja alegoryczna, którą można określić jako klerykalny spirytualizm, przy czym wyrazistość i moc autentycznych tekstów apokaliptycznych pozostawiono bez uwagi i właściwej egzegezy ${ }^{84}$.

Bardzo podobne wyobrażenie civitas Dei istnieje również w Kościele prawosławnym:

Zwłaszcza epoka bizantyjska w historii Kościoła mogła być odczuwana jako niezmienna i ostatecznie określona pod kopułą władzy cesarskiej, i dopiero po upadku Bizancjum wyjawiona została umowność i względność tej epoki, chociaż ani dla prawosławia greckiego, ani dla bałkańskiego, pozostających w niewoli tureckiej, nie stały się bliskimi te teorie apokaliptyczne, właściwe dla Kościoła wschodniego pierwszych wieków. [...] dusza prawosławia rosyjskiego, pomimo zewnętrznego klerykalnego spirytualizmu, przeważnie związanego z hierarchią, pozostała w swej głębi otwarta na przeczucia i lęk apokaliptyczny $[\ldots]^{85}$.

bez tej możliwości. Nieznane jest natomiast pojęcie czyśćca jako odrębnego miejsca lub stanu, co przyjęła dogmatyka katolicka. Dla akceptacji koncepcji trzeciego miejsca brak wystarczających podstaw dogmatycznych i biblijnych. Nie można jednak odrzucać możliwości stanu oczyszczenia, co właśnie jest wspólne dla nauki katolickiej i prawosławnej. [...] W istocie ważne jest nie rozróżnienie piekła i czyśćca jako dwóch różnych miejsc przebywania duszy po śmierci, ale jako dwóch s t a nó w - możliwości uwolnienia z cierpień piekielnych, przejścia ze stanu odrzucenia do stanu usprawiedliwienia".

83 Bułgakow, op. cit., s. 201.

$84 \quad$ Ibidem, s. 193.

85 Ibidem, s. 193-194. 
W konsekwencji opisywanych procesów nastapiło częściowe zeświecczenie władzy papieskiej w Kościele zachodnim (Bułgakow zauważa tutaj krytycznie, że katolicyzm „w instytucji papiestwa posiada w pełni zbudowana kopułe budowli Kościoła, która to kopuła całkowicie zakrywa niebo i jego gwiazdy"86), we wschodnim natomiast otworzyła się droga do sakralizacji władzy świeckiej. Porównując modele kultury opierające się na obu tych koncepcjach, trzeba jednak powiedzieć, że model zachodni ze swoim zapasem treści neutralnych i obowiazkiem uszlachetniania materii pozostawia ludzkiej historii nieco więcej swobody działania (co nie przeszkadza stwierdzić, że i dobre zamiary czasem źle się kończą).

\section{Czy dzięki apokatastazie powstaje system ternarny?}

Można by zaatakować koncepcję Miłosza i powiedzieć, że apokatastaza jest właśnie tym momentem w rosyjskim chrześcijaństwie, w którym binaryzm przechodzi w system ternarny, ponieważ obietnica odnowienia wszystkich rzeczy znosi ostry dualizm nieba i ziemi. Apokatastaza nie konstytuuje jednak systemu ternarnego, gdyż w przeciwieństwie do purgatorium nie jest trzecim, neutralnym miejscem, a zatem również nie tworzy neutralnego rezerwuaru, $z$ którego czerpać mogłaby kultura. Apokatastaza znosi dualizm w jedności. Bułgakow sprzeciwiał się przecież przede wszystkim wyobrażeniu czyśca jako miejsca. Przy tym przejście od dualizmu do owej idealnej jedności może być wytłumaczone tylko Boską wszechmoca, następuje ono bowiem po apokalipsie i Sądzie Ostatecznym, w konsekwencji których zbawieni zostają oddzieleni od potępionych. Wydaje się więc możliwe uznać apokatastazę za wzór dla opisywanego przez Hansena-Lövego zjawiska „przenicowania" i za swoisty schemat przebiegu procesów dynamicznych w systemach binarnych.

Dynamikę systemu ternarnego (a więc europejskiego) Łotman i Uspienski przedstawiaja jako wymianę między centrum (tj. kulturą oficjalną) a peryferiami (nieoficjalny, po części neutralny obszar kulturowy):

Myśliciele antyfeudalni czerpali ideały z określonych dziedzin otaczającej rzeczywistości - pozakościelnej państwowości, rodziny mieszczańskiej - i przenosili je do idealnej przestrzeni teorii społecznych, gdzie były poddawane heroicznej lub moralistycznej transformacji. Neutralna sfera życia stawała się normą, a wysoko zsemiotyzowane sfery „góry” $i$ „dołu” kultury średniowiecznej były wypierane do obszaru anomalii kulturowych ${ }^{87}$.

Rewolucje w kulturach ternarnych odbywają się, zdaniem obu autorów, głównie na poziomie retoryki. W swoim ostatnim dziele Kultura i eksplozja Łotman formułuje ten pogląd w następujący sposób: „twierdzenia współczesnych, a w ślad za nimi również historyków, o całkowitym zniszczeniu starego systemu są mieszaniną samooszukiwania się $\mathrm{i}$ haseł propagandowych" ${ }^{\prime 8}$.

$86 \quad$ Ibidem, s. 193.

87 Łotman, Us p i e n s ki, Rola modeli dualnych $w$ dynamice kultury rosyjskiej (do końca XVIII wieku), s. 19.

88 Ju. Łotman, Kultura i eksplozja. Przeł., wstęp B. Żyłko. Warszawa 1999, s. 225. 


\section{Odnowa w kulturze rosyjskiej ma zupełnie inny charakter:}

Dwubiegunowość i brak neutralnej sfery aksjologicznej prowadziły do tego, że nowość rozumiana była nie jako kontynuacja, lecz jako eschatologiczna zmiana wszystkiego. [...]

Proces dynamiczny nabiera w tych warunkach zasadniczo innego charakteru: zmiana przebiega jako radykalne odpychanie się od etapu poprzedniego. Naturalnym rezultatem tej sytuacji było to, że nowość powstawała nie ze strukturalnie „niewykorzystanej” rezerwy, lecz była rezultatem transformacji starego; by tak rzec, wywracania go na lewą stronę. Stąd z kolei powtórne zmiany mogły w rzeczywistości prowadzić do regeneracji archaicznych form. [...]

Te głębokie struktury rozwoju pozwalają właśnie mówić o jedności kultury rosyjskiej na różnych etapach historii. Właściwie w zmianach ujawnia się to, co niezmienne ${ }^{89}$.

W Kulturze i eksplozji znajdziemy jeszcze dobitniejsze sformułowania dotyczace tego samego problemu:

W systemach binarnych wybuch ogarnia ogół bytu. Bezwzględność tego eksperymentu nie ujawnia się od razu. Początkowo przyciaga on najbardziej maksymalistycznie nastrojone warstwy społeczeństwa poetycką wizją błyskawicznego zbudowania „nowej ziemi i nowego nieba”, swoim radykalizmem.

Cena, jaką trzeba płacić za utopie, staje się widoczna dopiero na następnym etapie. Charakterystyczną cechą momentów wybuchowych w systemach binarnych jest przeżywanie ich jako wyjątkowej, z niczym nie porównywalnej chwili w całych dziejach ludzkości. Chodzi tu nie o jakiś konkretny etap rozwoju historycznego, lecz o samo istnienie historii. W ideale jest to apokaliptyczne: „czasu więcej nie będzie". [...] Wiąże się z tym dążenie do zastąpienia prawodawstwa przez zasady moralne lub religijne. $[\ldots]$

Cudowne utopijne przeistoczenie człowieka w teorii zawsze zaczyna się od ofiary pokutnej, od przelewu krwi. W praktyce jest ono skazane na utonięcie we krwi ${ }^{90}$.

System ternarny pragnie dostosować ideał do rzeczywistości, natomiast binarny - wcielić w życie nie dający się urzeczywistnić ideał ${ }^{91}$.

Jeżeli odnowa przeżywana jest jako apokalipsa, kontynuuje Łotman, to każda utrwalającą się po niej władzę uważa się za Boską. Swoje zadanie formułuje ona jako urzeczywistnienie utopii. Podobny trop znajdujemy u Miłosza: różnica między rzeczywistością a zapowiadanym ideałem staje się według poety wkrótce oczywista i musi być utrzymywana w tajemnicy przez „spisek przeciwko prawdzie”:

Państwo ze swoją podniosłą konstytucją, wychowanie, literatura dążyły do ideału braterstwa, „nowy człowiek" był szlachetny i czysty. Ale tylko w teorii, która powoli narastała autonomicznie, dźwigając się jak wyspa koralowa nad powierzchnią morza. [M 162]

Żołnierze radzieccy, o których mowa w eseju Miłosza, czują się więc zmuszeni grać komedię raczej przed sobą niż przed pojmanym żołnierzem niemieckim:

Odgrywając komedię, bardziej przed samymi sobą niż przed jeńcem, żołnierze składali daninę temu, co powin no być, wiedząc zarazem, że po wręcz przeciwnych torach porusza się rzeczywistość. [M 162] 


\section{Co dalej?}

Wobec przedstawionego przez Łotmana i Miłosza modelu kultury rosyjskiej powstaje pytanie: jak w ogóle możliwe jest wyjście poza panujące w niej deterministyczne schematy? Łotman zajmował się tym pytaniem intensywnie w latach dziewięćdziesiątych ubiegłego stulecia, polemizując przy tym $\mathrm{z}$ metodami nouvelle histoire. Doceniał zasługi historyków szkoły długiego trwania i dokonany przez nich zwrot w stronę fenomenów kultury życia codziennego oraz badanie wolno przebiegających, masowych i na ogół nie uświadamianych procesów historycznych. Zarzucał im jednak deterministyczny sposób widzenia. Według Łotmana zbyt radykalnie odwrócili się oni od tzw. historii zdarzeniowej. Koncentrując się wyłącznie na zjawiskach długiego trwania, $\mathrm{z}$ konieczności traktowali historię tak, jakby nie dopuszczała ona świadomych zmian ${ }^{92}$. Natomiast - zdaniem Łotmana - okresy, kiedy rozwój wydarzeń jest przewidywalny i odbywa się niejako poza świadomością swoich aktorów, przerywane sa przez eksplozje („wzrywy”), które nie tylko przyspieszaja wypadki, lecz także daja jednostkom i grupom okazję do zmiany biegu historii. Łotman tłumaczył to zjawisko, sięgajac do teorii bifurkacji sformułowanej przez chemika Ilię Prigożyna. W procesach chemicznych w momencie bifurkacji (łac. bifurcus - 'rozszczepiony, rozgałęziony') powstaje cała wiązka możliwości, z której ostatecznie tylko jedna będzie wykorzystana. Wyjątkowość tego stanu sprawia, że nawet w reakcjach chemicznych wynik końcowy nie daje się przewidzieć. W podobny sposób Łotman widział sytuację historyczną w latach dziewięćdziesiątych ubiegłego wieku, wyrażając nadzieję, że doprowadzi ona do głębszych przekształceń i popchnie również Rosję w nieco innym niż dotychczas kierunku:

Zasadnicze zmiany w stosunkach Europy Wschodniej i Zachodniej, dokonujące się na naszych oczach, stwarzają być może szansę przejścia na ogólnoeuropejski ternarny system i oznaczają rezygnację z ideału zburzenia „starego świata do fundamentów” po to, by potem na jego gruzach zbudować nowy. Byłoby historyczną katastrofa, gdybyśmy przegapili tę okazję ${ }^{93}$.

Podjęcie - $\mathrm{z}$ wielu stron tak przecież potrzebnego - dialogu Łotman uważał za żywotny interes Rosji. Jeżeli taki dialog doszedłby do skutku, to kultura rosyjska nie stanowiłaby tylko powielenia zachodniego porządku: ,jest mało prawdopodobne, że nowy porządek będzie zwykłą kopią ładu zachodniego. Historia nie zna powtórek. Lubi ona nowe, nieprzewidywalne drogi" ${ }^{94}$.

W tym dialogu Kościół ortodoksyjny może odegrać istotną rolę. Jako główny nosiciel tradycji w Rosji jest on nawet w sposób szczególny do tego powołany. Ortodoksja, ortodoksja rosyjska, jak każda zawiera bowiem zarówno elementy binarne (znajdujące oparcie w podwójnej, Boskiej i ludzkiej, naturze Chrystusa), jak i ternarne (mające uzasadnienie np. w dogmacie o Trójcy Świętej). Nie chodzi tu zresztą tylko o działalność hierarchów, lecz o koncepcje teologiczne, świadome także swojej roli kulturotwórczej. Dużej wagi tematu świadom był Bułgakow, który

92 Zob. Ju. Łotman, Uniwersum umysłu. Semiotyczna teoria kultury. Przeł., przedm. B. Żyłk o. Gdańsk 2009.

$93 \quad$ Łot ma n, Kultura i eksplozja, s. 236.

$94 \quad$ Ibidem, s. 232. 
również chciał połączyć myśl apokaliptyczną z refleksją ukierunkowaną na historię, przyznając tej ostatniej większe znaczenie, niż ma to miejsce np. w manicheizmie: „Historię należy przeżyć i wypełnić, a nie tylko byle jak przejść przez nią jak przez mroczny i pusty korytarz prowadzacy do Królestwa Niebieskiego" ${ }^{95}$.

Przerzucanie mostów między myśleniem apokaliptycznym a historią wymaga jednak oprócz ogólnej gotowości, również intensywnej pracy, tworzenia budowli konceptualnej, która umożliwiłaby głębsze zakorzenienie się rosyjskiej religijności i kultury w historii. Fakt, że rosyjskie ośrodki decydenckie nie wypełniły do tej pory oczekiwań Łotmana, a nawet wręcz przeciwnie - od początku XXI wieku zdają się raczej dążyć do odtworzenia modelu sprzed przeobrażeń ustrojowych - nie zmienia nic w zobowiązaniach, jakie projekt ten nakłada na społeczeństwo rosyjskie, a szczególnie na jego elity. To w ich wnętrzu ma szansę dokonać się dziejowa praca.

Nie sposób nie zauważyć, że Łotman postulując przeobrażenie strukturalne w rosyjskiej kulturze opuszcza archimedesowy punkt widzenia kulturologii i przyjmuje pozycję w obrębie jej poprzedniczki, kulturozofii, dla której kultury dzielą się na „lepsze” i „gorsze” ${ }^{6}$. W szczególnych przypadkach jednak nawet kulturolodzy akceptują podobne postępowanie:

Ostrzeżenie przed katastrofą i nawoływanie Łotmana, że Rosja powinna opuścić kulturę dualistyczną i przyłączyć się do - ocenianej przez niego wyżej - trynitarnej formy kulturowej, to kulturozoficzne (w istocie dwuwartościowe) wypowiedzi. Sa one jednak częścią tego rodzaju kulturozofii, która rozsadza system kulturozoficzny i pozwala stadium kulturozoficzne pozostawić ostatecznie za sobą ${ }^{97}$.

Kiedy żąda się strukturalnych zmian kultury, kiedy chce się ją poprawiać, nie sposób pozostać na pozycji kulturologicznej, dla której każda kultura jest tak samo „dobra”. Nie można jednak zarzucić Łotmanowi eurocentryzmu, nie postuluje on bowiem po prostu przejęcia modelu europejskiego przez Rosję, lecz zachęca do wielopłaszczyznowego dialogu z kulturą europejską. Dialog taki byłby zupełnie czymś innym niż dotychczasowa europeizacja Rosji, dokonywana często pod przymusem. Według samego Łotmana niezbędnym etapem takiego dialogu jest tłumaczenie obcych treści na język własnej kultury. W wyniku tego tłumaczenia powstaje wszakże wartość dodatkowa, „nowe”, nie będące już kopią oryginału.

Bułgakow, op. cit., s. 194.

I. Smirnov i R. Grübel (Die Geschichte der russischen Kulturosophie im 19. und frühen 20. Jahrhundert. „Wiener Slawistischer Almanach” t. $44\langle 1997\rangle$, s. 5) w następujący sposób wyjaśniają różnicę między kulturozofią a kulturologią: „Kulturozofia oznacza - w przeciwieństwie do kulturologii - podejście do kultury, które opiera się na jej rozłożeniu na aksjologiczne dychotomie. Kulturozofia dąży do wyższego i ostatecznego, korzystającego z wartościowania, rozumienia kultur, które w porządku dysjunktywnym mogą być uważane za fałszywe lub prawdziwe. [...] W założeniu, że jakaś określona kultura ma jedyne i wyłączne, powszechnie obowiązujące znaczenie, kulturozofia styka się z filozofią. Naukowa teoria kultury, kulturologia, dojrzewa stopniowo wewnątrz kulturozofii, by zająć wreszcie jej miejsce. Punkt widzenia kulturozofa położony jest zawsze w obrębie jednej z obu (porównywanych) kultur, podczas kiedy kulturolog tak się zachowuje, jakby stał poza wszystkimi kulturami”. Zdaniem obu badaczy, z przyczyn historycznych kulturologia powstała w Rosji szczególnie późno, a kulturozoficzny sposób myślenia ciągle jeszcze odgrywa tam dużą rolę. Ibidem, s. 17. 
Czy Miłosz daje nam chociażby przeczucie możliwości zmiany, wyjścia poza pozorny determinizm rosyjskiej historii? Przyjrzyjmy się następującemu cytatowi:

Rosyjski pisarz Dymitr Mereżkowski tak powiedział jednemu ze swoich polskich rozmówców: „Rosja jest kobieca, ale nigdy nie miała męża. Gwałcili ją tylko Tatarzy, carowie, bolszewicy. Jedynym mężem dla Rosji mogłaby być Polska. Ale Polska była za słaba”. [M 166]

Jaką naukę można dzisiaj wyciagnąć z powielanego tu przez Mereżkowskiego/ Miłosza wyobrażenia o kobiecości Rosji? Słusznie zauważano, że o Rosji mówi się często językiem ginekofobicznym. Stworzenie $z$ tego cytatu to zresztą raczej nie kobieta, lecz znana $z$ dyskursu o tym kraju „russkaja misticzeskaja baba”, jak ja nazwał Bierdiajew. Rosyjskiego filozofa zainspirował przede wszystkim pewien fragment $\mathrm{z}$ książki Wasilija Rozanowa Wojna 1914 goda i russkoje wozdrożdienije. Rozanow opisuje w nim masochistyczne zachwycenie, którego doznał w obliczu galopującego ulicą oddziału kawalerii:

Nagle poczułem, że nie tylko „boję się”, ale jestem tym urzeczony, zaczarowany jakimś dziwnym oczarowaniem, którego po raz pierwszy w życiu - właśnie teraz - doświadczyłem. Stało się coś dziwnego: nienaturalnej wielkości męskość, którą miałem przed sobą, jakby zmieniła całą moją wewnętrzną strukturę, odrzuciła ją, zamieniając w kobiecość. Poczułem wewnątrz siebie niezwykłą czułość, słodkie odrętwienie i senność... Serce zamarło z miłości... Pragnąłem, by jeźdźcy jeszcze bardziej wyolbrzymieli, by było ich jeszcze więcej... Ta potęga fizjologii, potęga życia i najpewniej źródło życia wywołały we mnie typowo kobiece uczucie uległości, pokory i nienasycenia w pragnieniu „być blisko”, widzieć, nie spuszczać wzroku... Przypominało to stan zakochania dziewczyny. [...] Siła - oto jedyne piękno w świecie... Siła - to ona zniewala, przed nia padamy, do niej, wreszcie, modlimy się... ${ }^{98}$

Scena ta, zdaniem Bierdiajewa, doskonale odzwierciedla „kobiecość” „duszy rosyjskiej":

Kobiecość Rozanowa, z takim mistrzostwem wyrażona, to również kobiecość duszy narodu rosyjskiego. Historię powstania państwowości rosyjskiej, największej państwowości na świecie, tak niepojętą w dziejach „bezpaństwowego” narodu, można zrozumieć dzięki tej tajemnicy. Naród rosyjski ma dar pokory wobec państwa, dar uległości jednostki przed kolektywem. Naród rosyjski nie czuje się mężem, wciąż czeka na narzeczonego, czuje się kobietą w obliczu potęgi państwa, urzeka go siła, postrzega siebie poprzez Rozanowowskie ,ja na chodniku” w chwili przejścia kawalerii. [...]

Dla Rozanowa nie tylko istota armii, lecz i istota władzy państwowej zawiera się w tym, że „wszystkich nas zmienia w kobiety - słabe, drżące, obejmujące powietrze..." ${ }^{99}$

Idąc tropem tego ginekofobicznego dyskursu wolno powiedzieć, że istnienie w eseju Miłosza cytatu przypisanego Mereżkowskiemu świadczyć może o ukrytym życzeniu odwrócenia funkcji: czyż nie chodzi tu o przejęcie roli „mężczyzny” w celu ujarzmienia kapryśnej baby - Rosji? Życzenie takie wszakże nigdy nie spełni się, gdyż Polska, jak wynika z cytowanego „aforyzmu”, nie jest na to dość męska. Wydaje się więc, że ani dla Rosji, ani dla Polski nie ma ratunku.

$Z$ tego rodzaju definicją małżeństwa trudno zresztą dyskutować. Jest jedak

98 W. Rozanow, Wojna 1914 goda i russkoje wozrożdienije. Pietrograd 1915. Cyt. za: N. Bierdiaj ew, O „wiecznie babskim” $w$ duszy rosyjskiej (fragmenty). W zb.: Dusza polska i rosyjska, s. 141. Rosyjski oryginał ukazał się w 1915 roku.

99 Ibidem. 
możliwe zobrazowanie wzajemnych stosunków między Polską a Rosją na podstawie innej definicji tego związku. „Małżeństwo” dwóch kultur według Łotmana oznacza wymianę, tj. komunikację na wielu poziomach, między dwojgiem suwerennych partnerów. Uległość po którejkolwiek ze stron byłaby tu niewskazana. W relacji Rosji i Polski nie brakuje uczuć, gorzej z obopólnym szacunkiem i zrozumieniem; toteż zalecana jest ostrożność. Małżeństwo to również wspólnota dynamiczna, powołana na ogół do stworzenia nowego życia - nowych wartości kulturowych. To nowe życie dziedziczy wiele po każdym $z$ rodziców, ale nie jest do końca przewidywalne - gdyż nowe to po prostu nowe. Prawdopodobnie jednak można to wszystko zrobić bez „rodzinnych” metafor, które w stosunkach polsko-rosyjskich nie mają najlepszych tradycji. W eseju Miłosza nie znajdziemy, niestety, podstaw do nowej interpretacji wzajemnych stosunków Polaków i Rosjan w przyszłości ${ }^{100}$.

\section{„Obca” Rosja}

Łotman i Miłosz reprezentuja podobne pozycje w ocenie kultury rosyjskiej. Eseiście nie udaje się jednak uwolnić z pęt układu podwójnego wiązania. Wywodom Miłosza na temat piętna, jakie odcisnęła na kulturze rosyjskiej gnoza, brak również można odnieść takie wrażenie - po prostu chęci, by wyjść poza determinizm i nieskończoną powtarzalność rosyjskiego losu. Jest to szczególnie zaskakujące, jeżeli weźmie się pod uwagę uwikłanie samego Miłosza w gnozę. W eseju Tygrys pisarz bierze na celownik dualistyczne prady w kulturze europejskiej XX wieku, definiuje sam siebie jako (neo)gnostyka i w końcu pokazuje drogi wyjścia $z$ dualizmu. Wydaje się zatem wręcz zdumiewające, iż rosyjski dualizm pojawia się $\mathrm{w}$ eseju Rosja jako fenomen całkowicie obcy kulturze europejskiej i samemu poecie. Tymczasem właśnie heterodoksje były w wieku XX dla kultury naszego kontynentu źródłem wielorakiej inspiracji ${ }^{101}$. Miłosz nie dostrzega również, że narodowy socjalizm, największy kryzys kultury europejskiej ubiegłego stulecia, oznaczał także regres do wyobrażeń dualistycznych. Tutaj Miłosz podąża śladami swojego chyba najważniejszego mistrza - Jasinowskiego, którego percepcja wydaje się w podobny sposób zakłócona przez układ podwójnego wiązania ${ }^{102}$. Podmiot eseju Rosja przyznaje niejako na marginesie, iż sam nosi w sobie również piętno dualizmu ${ }^{103}$,

Esej ten nie jest, oczywiście, jedynym tekstem Miłosza na temat Rosji i literatury rosyjskiej. $Z$ biegiem lat obraz tego kraju i jego literatury stawał się u poety i profesora bez wątpienia bardziej zróżnicowany i co najmniej w niektórych wypadkach można nazwać Miłosza ich znawca (zob. wydaną przez „Zeszyty Literackie” antologię Cz. Miło s za Rosja. Widzenia transoceaniczne 〈T. 1: Dostojewski-nasz współczesny. Wybór tekstów B. Tor u ń czy k, M. Wój cia k. Oprac., układ tomu B. Tor uń c zy k. Wstęp C. C a va n a gh. Warszawa 2010; t. 2 (2011): Mosty napowietrzne. Wybór, oprac., układ tomu B. Toruńczyk. Współpr. M. Wójciak, M. Nowak-Rogoziński. Wstęp M. Kor nat t). Miłosz nigdy chyba jednak nie powrócił do swojej „syntezy” i nie omawiał szerzej poglądów wyrażonych w eseju Rosja.

Zob. M 161: „Przede wszystkim [...] z dużą wyrazistością powróciło to, co czytałem o sektach 
i wskazuje na podobieństwa kultury polskiej i rosyjskiej ${ }^{104}$, zasadniczo jednak tę druga postrzega jako „niekompatybilną” z europejską. Esej pozostawia wrażenie, że Rosja jest dla Europy obca, wręcz niesamowita - „unheimlich”. Niewątpliwie utrudnia to recepcje Rosji w Europie Zachodniej, a także w elitach rosyjskich ${ }^{105}$. Uważający się za oświeconego czytelnik zachodnioeuropejski szybko zidentyfikuje w eseju swój własny przesąd, który, jak słusznie czy niesłusznie sądzi, dawno zwalczył. Niewykluczone, że po zrobieniu tego odkrycia poczuje się zwolniony z wszelkiej dalszej refleksji. Rosjanin natomiast przypomni sobie znany już od epoki Mickiewicza ton, wyzywający i odpychający jednocześnie, w którym apostrofa „do przyjaciół” łączy się z radykalnym stwierdzeniem ich obcości. Nie odpowiedzą oni zatem wcale, spychając „wiedzę” do podświadomości, lub spróbują - jak Puszkin - odpowiedzieć z pozycji siły, uciekając do stóp Miedzianego Jeźdźca. Tak więc każdy pozostanie wierny swojej starej roli w układzie podwójnego wiązania. I nawet likwidacja samego układu nikogo automatycznie nie uwolni od utrwalonych przezeń schematów komunikacji.

Jeżeli jednak Rosja wydaje się nam „niesamowita”, to w dużej części nie z powodu własnej „niekompatybilności” z kultura europejską. Gdyż „niesamowite” przeraża nas według Freuda nie dlatego, że jest obce, lecz - wręcz przeciwnie - dlatego, że stanowi tę część „swojego”, której nie akceptujemy i którą w związku z tym wyparliśmy do podświadomości. Gdy tę wyparta część siebie widzimy u kogoś innego, niepokoi nas ona i wzbudza lęk, jest właśnie „unheimlich”" ${ }^{106}$. Tak należy wyjaśnić centralną rolę, jaką zajmuje w Rosji fragment Ustępu Mickiewicza, taki jest wynik psychoanalizy, którą Miłosz przeprowadził w eseju ${ }^{107}$.

Jednak prawda ta nie zostaje wypowiedziana przez podmiot refleksji. „Ja”, które poddaje się w eseju analizie, wykonuje swoje zadanie bez zarzutu, obnażając własny kompleks. Inaczej wygląa to w przypadku ,ja” odgrywającego rolę analityka: część swojej pracy pozostawia on czytelnikowi, żyjącemu w innym czasie i wolnemu od uwikłań podwójnego wiązania. Gdyż obnażenie „polskiego kompleksu" i negatywnego afektu w stosunku do Rosji ma naprawdę sens tylko wtedy, gdy stanie się przedmiotem wszechstronnej dyskusji. Okoliczności zewnętrzne dla takiej dyskusji są dziś nieporównanie lepsze niż wtedy, kiedy powstawała Rodzinna Europa. Nawet jeżeli nie można liczyć na wsparcie rosyjskich władz politycznych, trzeba poszukiwać partnerów do takiej dyskusji wśród Rosjan.

wschodniego chrześcijaństwa, w pewnym sensie dla mnie bliskich, ze względu na "wschodnią" cząstkę we mnie".

Zob. M 163: „Polacy są dostatecznie pokrewni Rosjanom i dostatecznie zagrożeni od wewnątrz przez słabość swojej indywidualnej etyki, żeby drżeć".

Historyczne dowody recepcji eseju znajdziemy np. w korespondencji A. Wali ckieg o z Cz. Miłoszem, cytowanej w „intelektualnej autobiografii” filozofa i historyka idei (Spotkania z Miłoszem 〈Londyn 1981); wyd. rozszerz. pod zmienionym tytułem - Zniewolony umysł po latach 〈Warszawa 1993〉).

F r e u d, Niesamowite, s. 244.

Wprawdzie Polacy są od końca XVII wieku w przeważającej liczbie katolikami, można by jednak długo dyskutować, czy polska kultura jest ternarna. Jako pierwszy argument na „nie” mógłby służyć fakt, że owa pośrednia strefa społeczna, trzeci stan lub klasa średnia ciagle jeszcze stosunkowo słabo zaznaczają się w polskim społeczeństwie. 
Abstract

MAŁGORZATA ZEMŁA Ludwig-Maximilians-Universität, Munich

MIŁOSZ, MICKIEWICZ, AND RUSSIA

The objective of the article is an analysis of Czesław Miłosz's essay Russia (Rosja) taking into consideration its most important pre-text, Adam Mickiewicz's Item (Ustęp) to Forefathers' Eve Part III (Dziady, część III). The starting point of Miłosz's text is a contrastive comparison of Polish (or European) and Russian culture and mentality. The communicative situation outlined in this manner is a reflection of Polish-Russian political state of affairs at the time of the essay's composition which can be described as a "double-bind" arrangement. The subject of the piece by Miłosz adopts in this arrangement the role of a victim, at the same time identifying itself with its national community, while Russia performs the role of an oppressor. In psychiatric descriptions of double bind the preservation of the persecutor's negative image is necessary for the victim to retain its internal integrity. The essay's subject is therefore trying to fulfil its role referring to negative stereotype about Russia, and in this stereotype is looking for an explanation for its own "obsession" about the country. On the other hand, Miłosz in Russia carries out a kind of literary psychoanalysis which offers possibilities of going beyond the uncompromising polarisation of the Poles and the Russians. Indicating the Gnostic roots of Russian culture, the poet forms bases of metadiscourse about Russia since cultural heterodoxy is by no means only Russian phenomenon. It is rather the reverse: Gnostic influences are seen in European culture with a naked eye, especially in the $20^{\text {th }}$ century. As a result of this psychoanalytical process, Russia is manifest in Miłosz's essay as an embodiment of Freud's "the uncanny" ("das Unheimliche"). According to Sigmund Freud, "the uncanny" terrifies us not because it is alien but contrary to that, because it is a part of "our" which we have denied and for that reason it causes fear. This truth, however, is unpronounced by the essay's subject and in Miłosz's piece it remains somewhat hidden in the shadow of stereotypical images about Russia. 